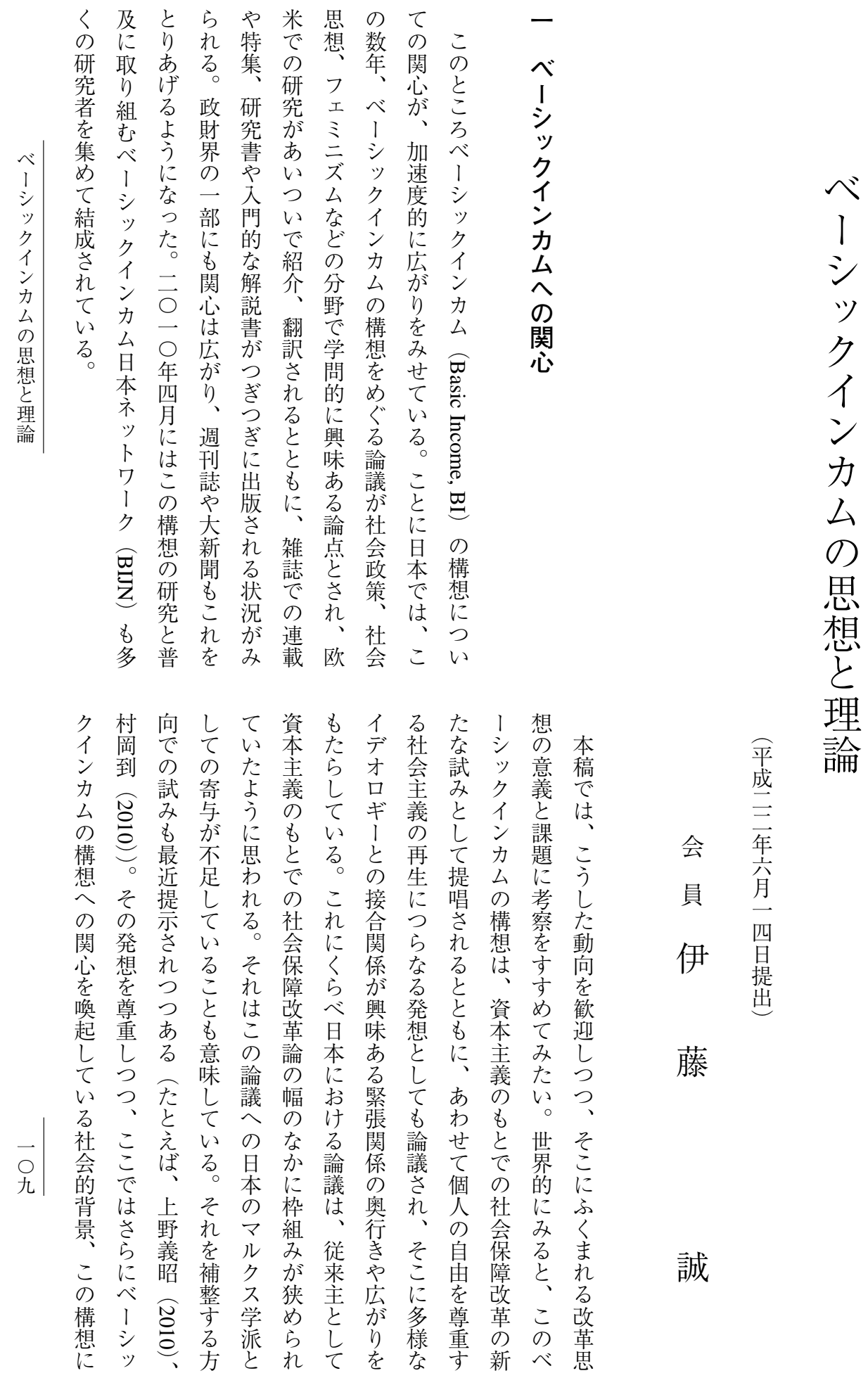


の゙゙リ゚資と質 ゔ

は、調の基安をリ払住そなな゙ず想ど! な

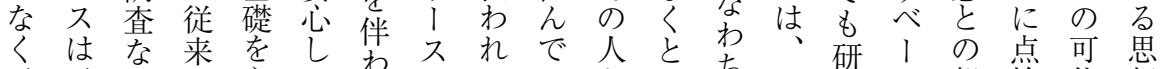

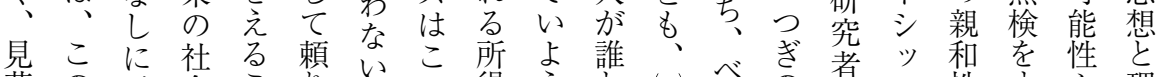

苦の 、 社 る

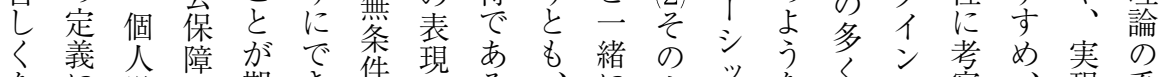

なに単給期き件にる、当、的に察、現系

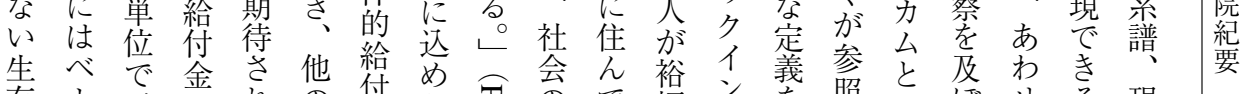

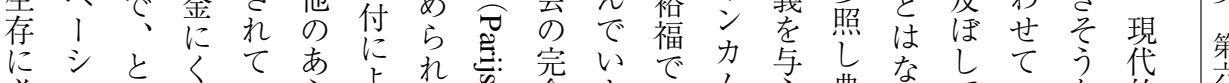

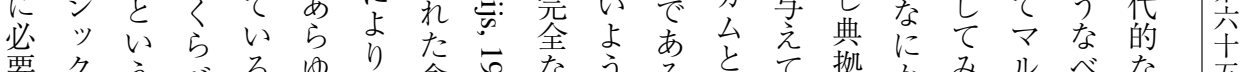

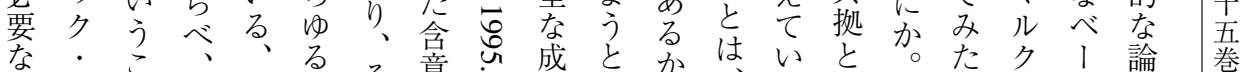

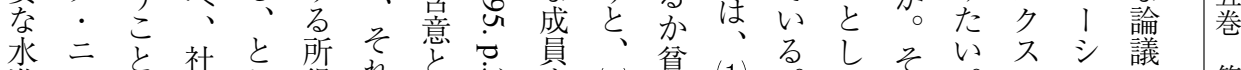

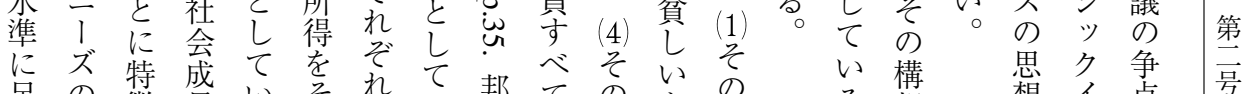

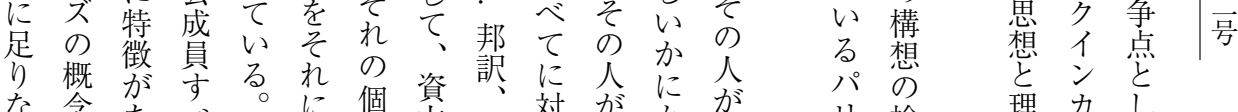

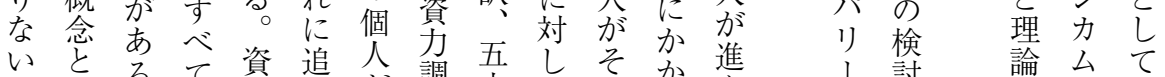

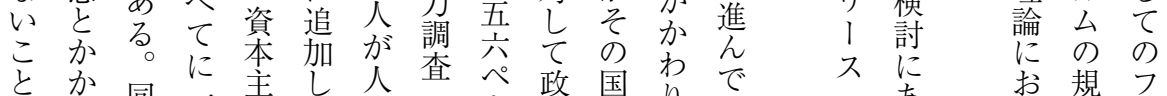

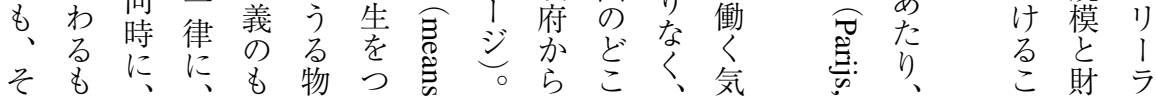

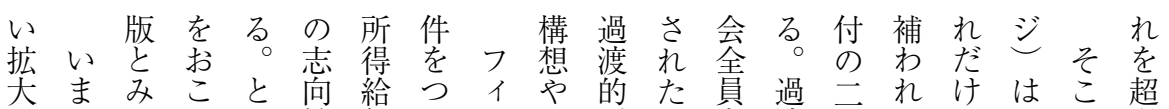

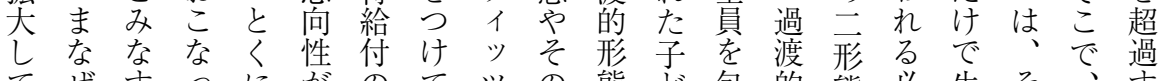

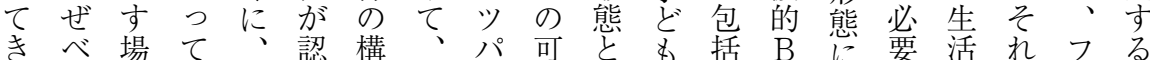

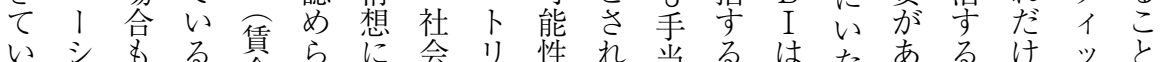

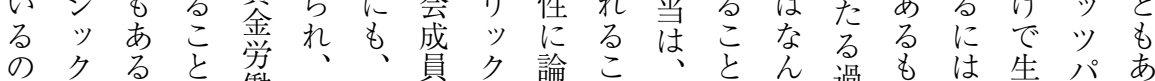
のクると学、、員ク論こ働

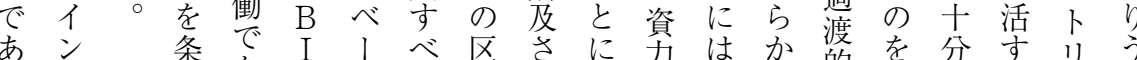

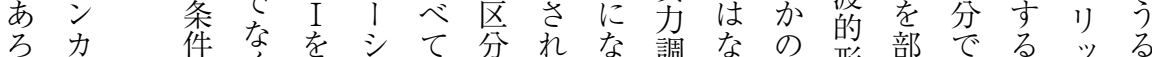

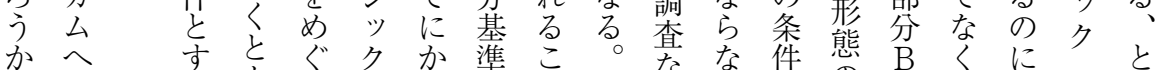

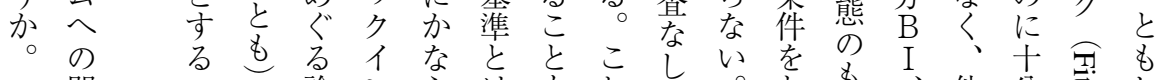
関 参 ケ 論 ン

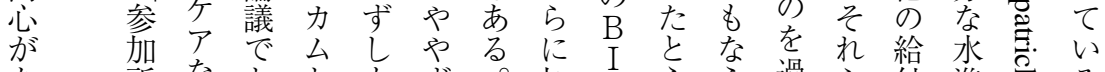

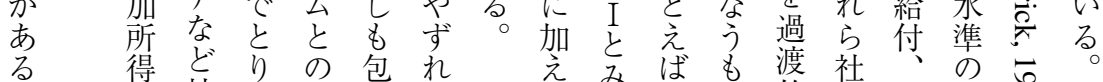

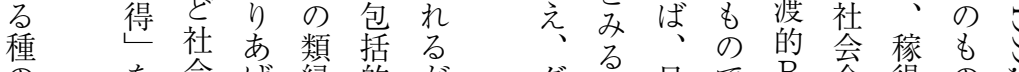

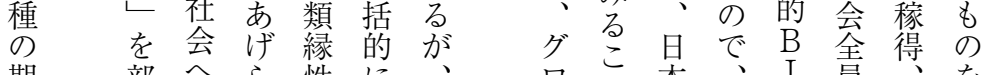

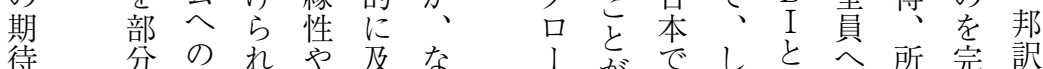
崻感 $\mathrm{B}$ 有 感 $\mathrm{B}$ 有 る

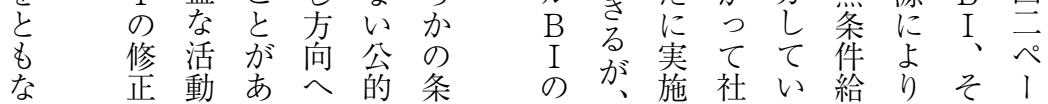




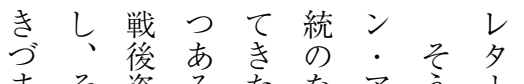
まそ資る た た な

深対義て 本ら视 み で

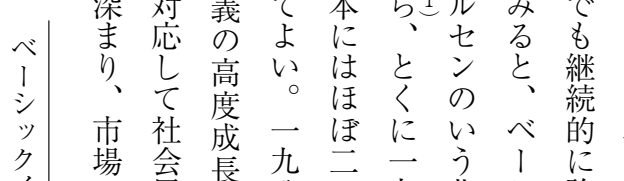

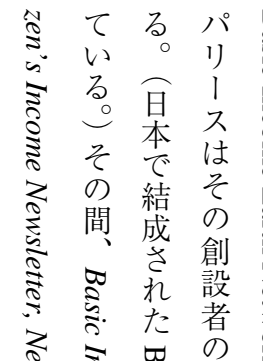

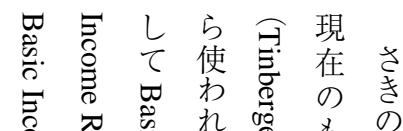

㕕長儿吕九北 シ 論

競主 七

㕕 的 義 年 代 時 年 社 イ

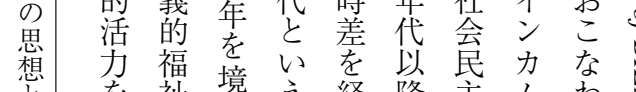

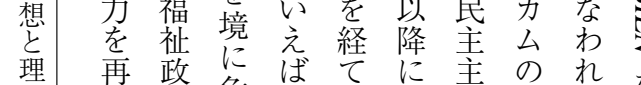

論 評策危機て、に 主 の れ

価や機一そきま的想き

し ケ方 の り、福 へて

さ ン 編、驇継国関る

ざ主 時 れ 移的毛 は

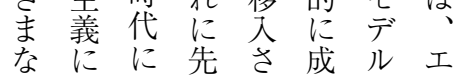

分名転立 れ 長の ス

野ゆ換つつ伝 ピ

$\frac{\sqrt{2}}{2}$

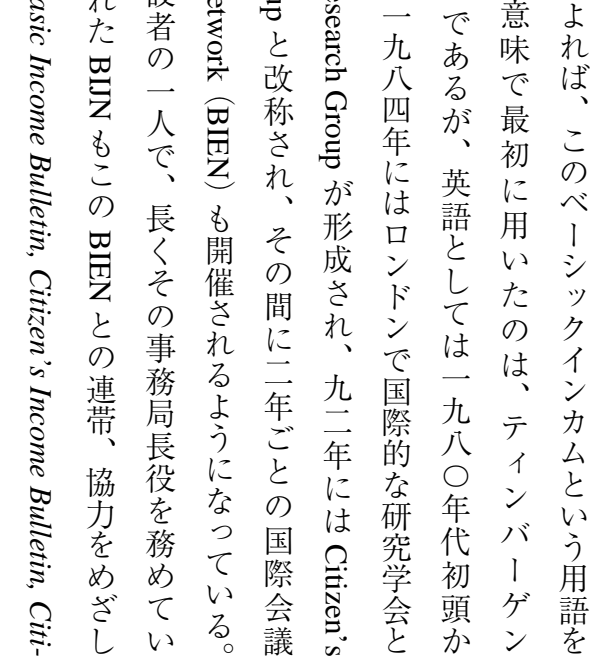

度正新る強きしに

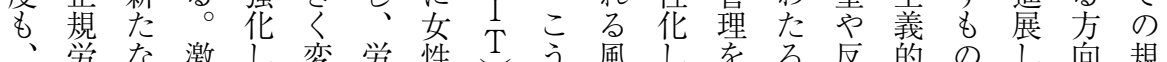
家働貧 増て 容働のをし潮よ軽歴感専とてに制 族者困すきささ組低再たもう減史恕制みい新を も老問るたせ合賃再編生としの広支らた自緩 そ中題韭こて の金編自じす緩進㤁配れ和 れ心户正と、組労基曲て る和路りのてて他主.

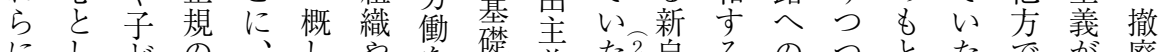

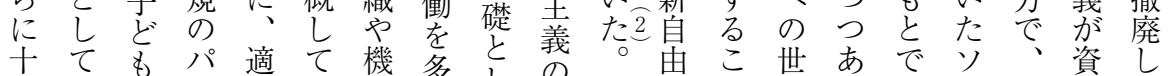
分きや! 合個能様乙政主と紀つの連か本、

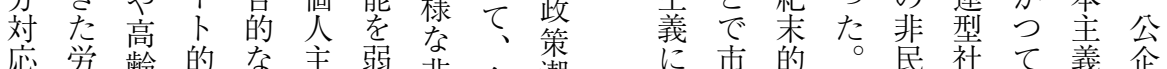

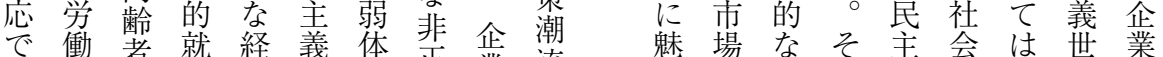
き組 者労済的化正業流 力咸の的主資界を な合ケ形的なし規のは多拈塞よで義本の 民

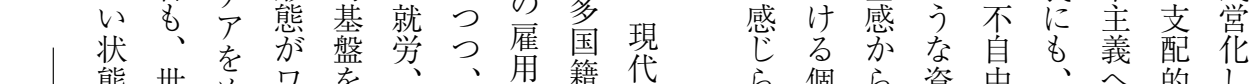
一

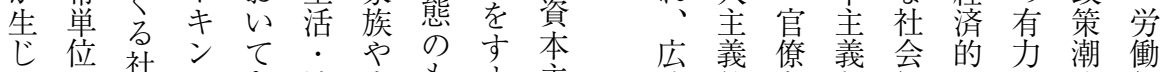
て で会グき消家も方主美的主と経なな流組 いの同プた費庭と㣻め義期な義社済摩代と合 た 社題ア 枩 と保を生よ方イ割量、報よ热義へ予、線傾体

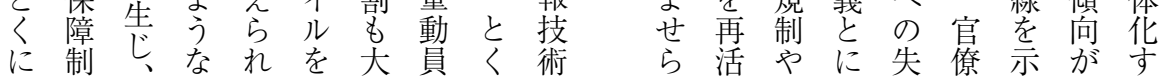



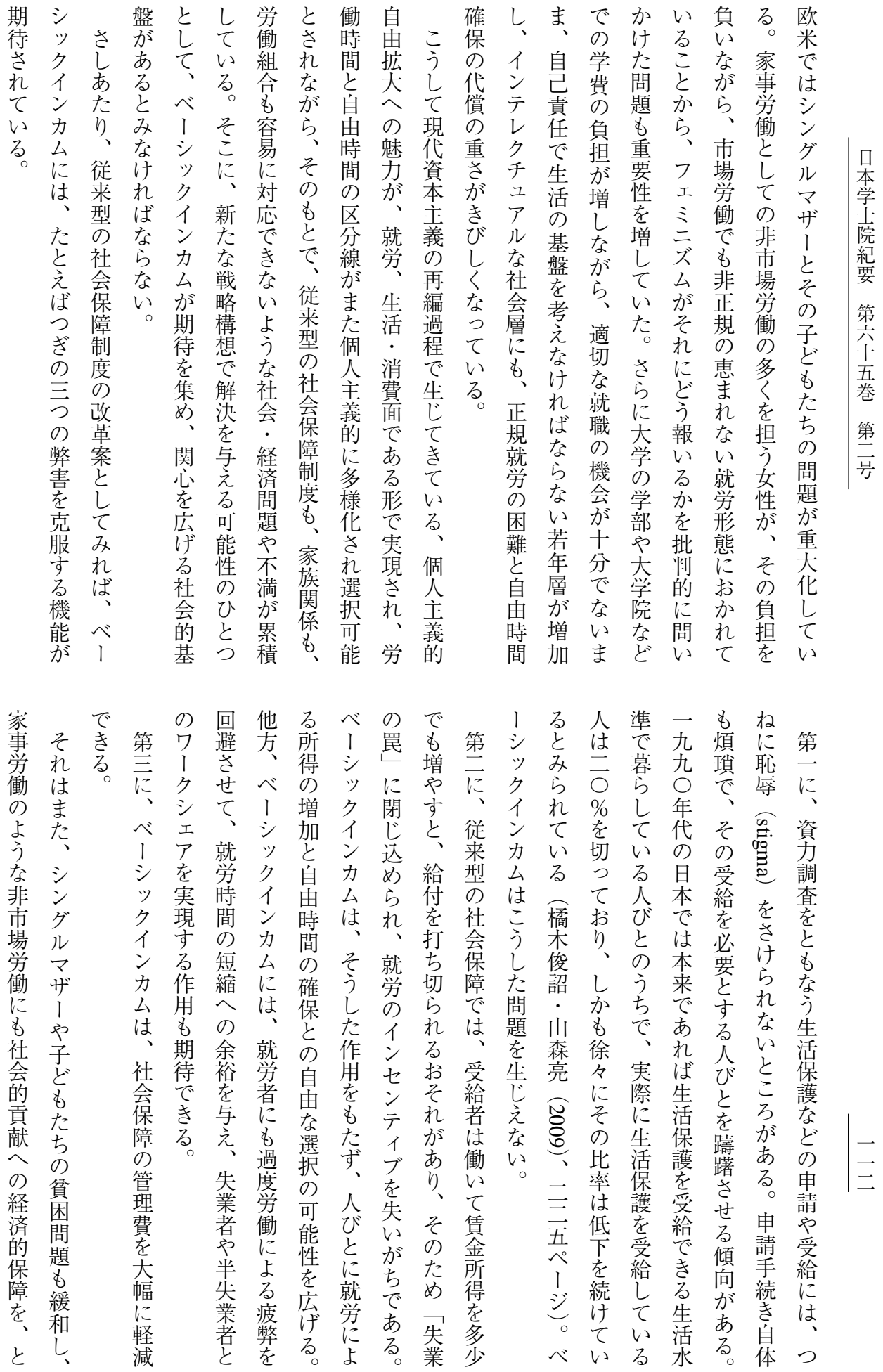

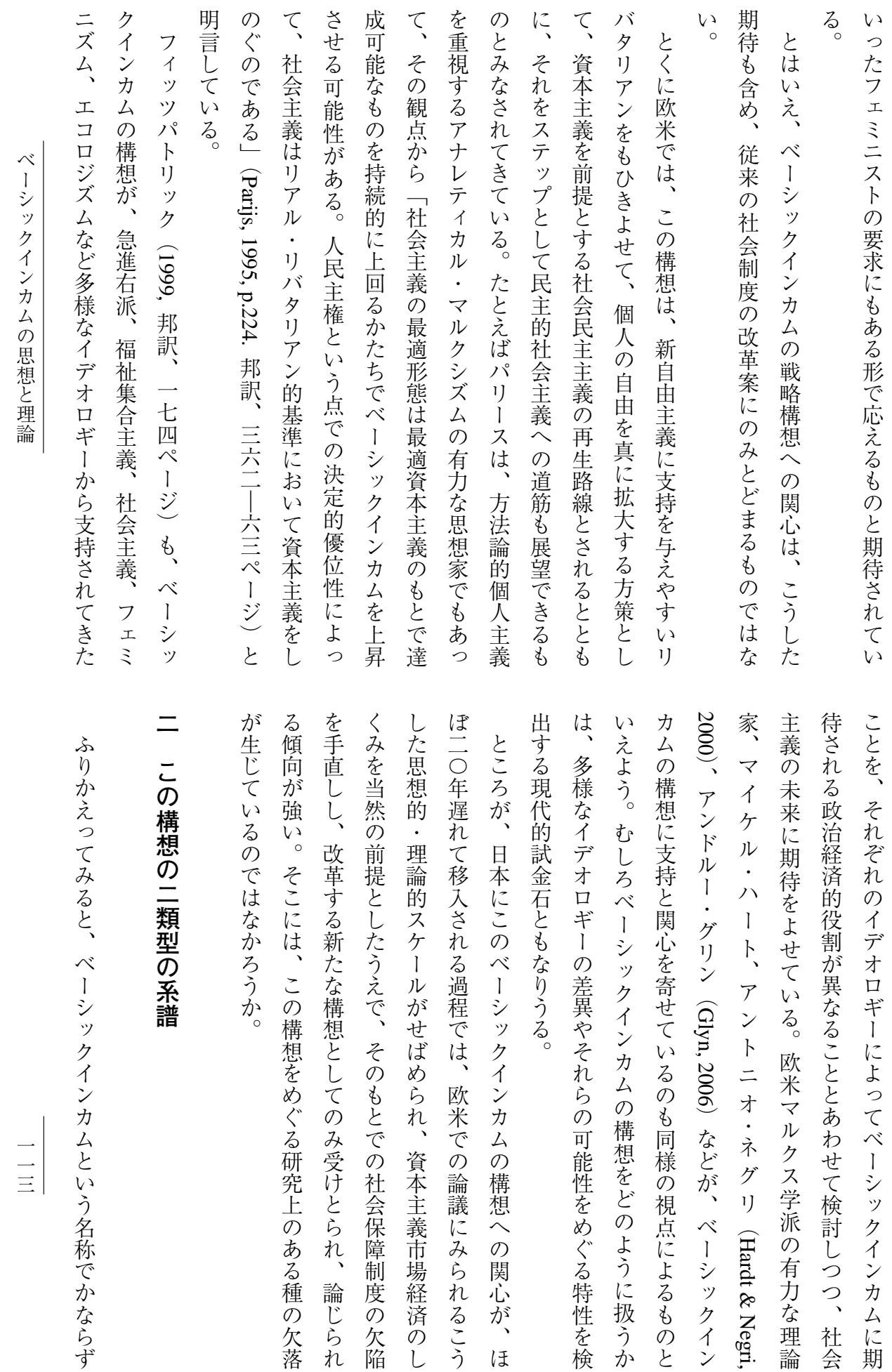


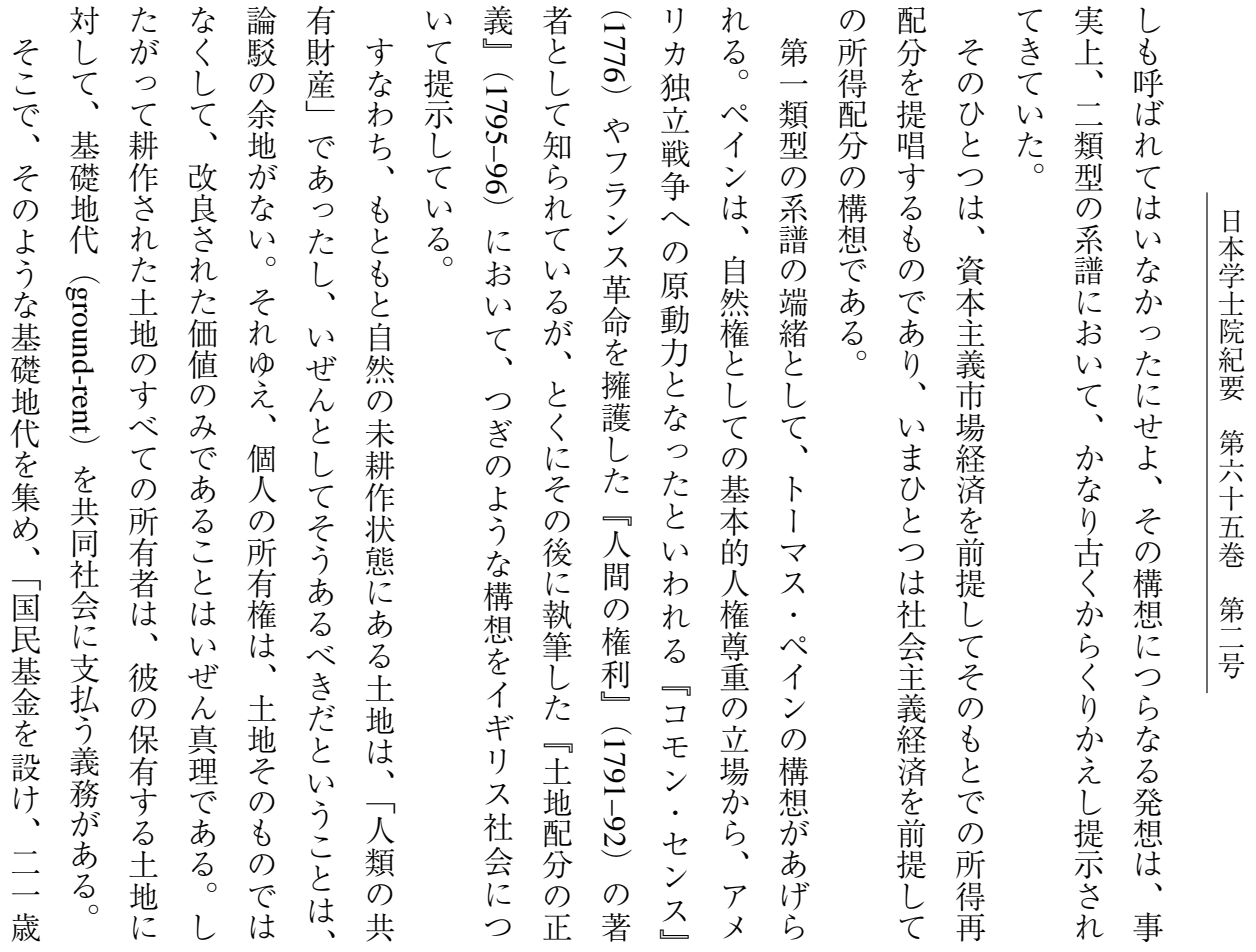

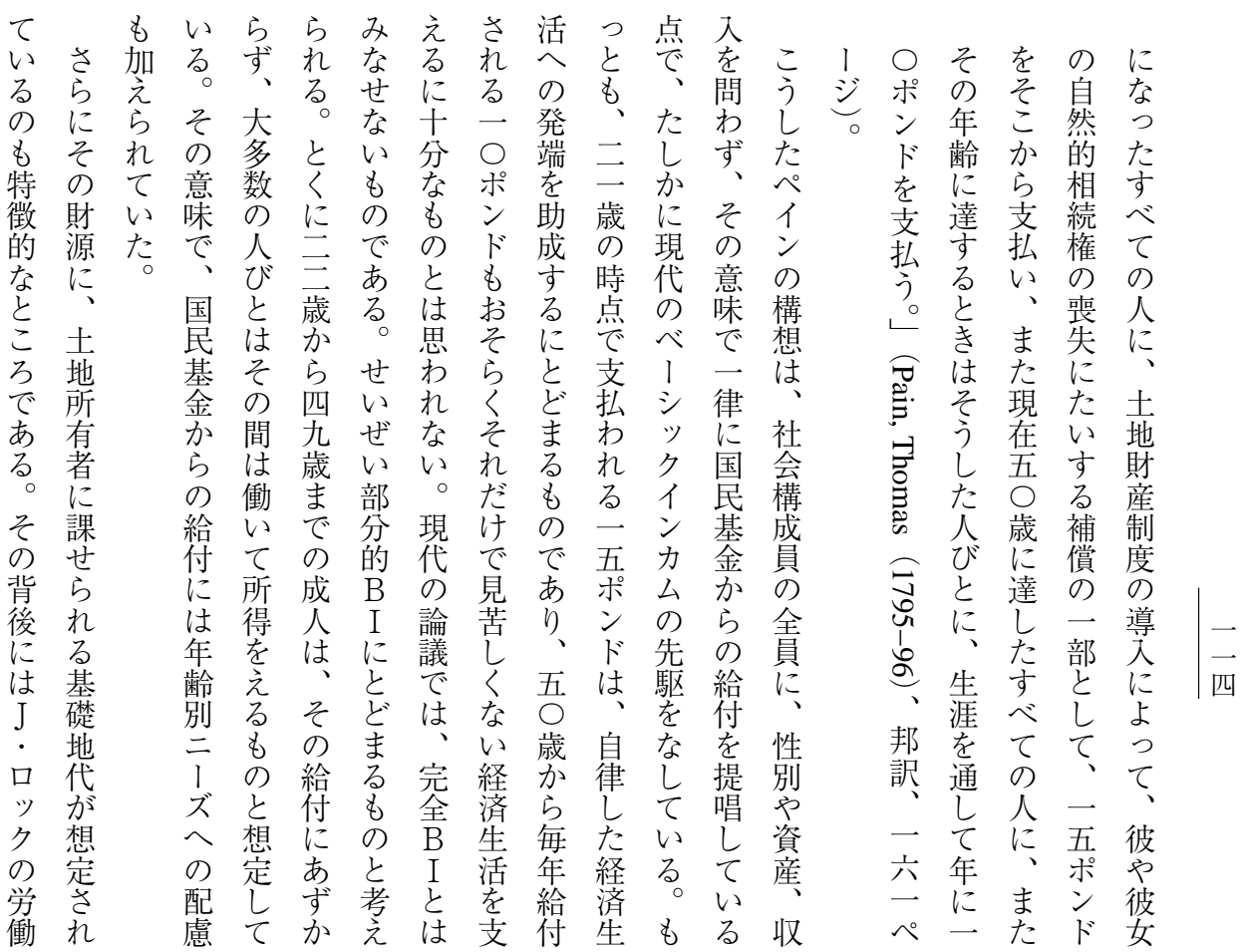




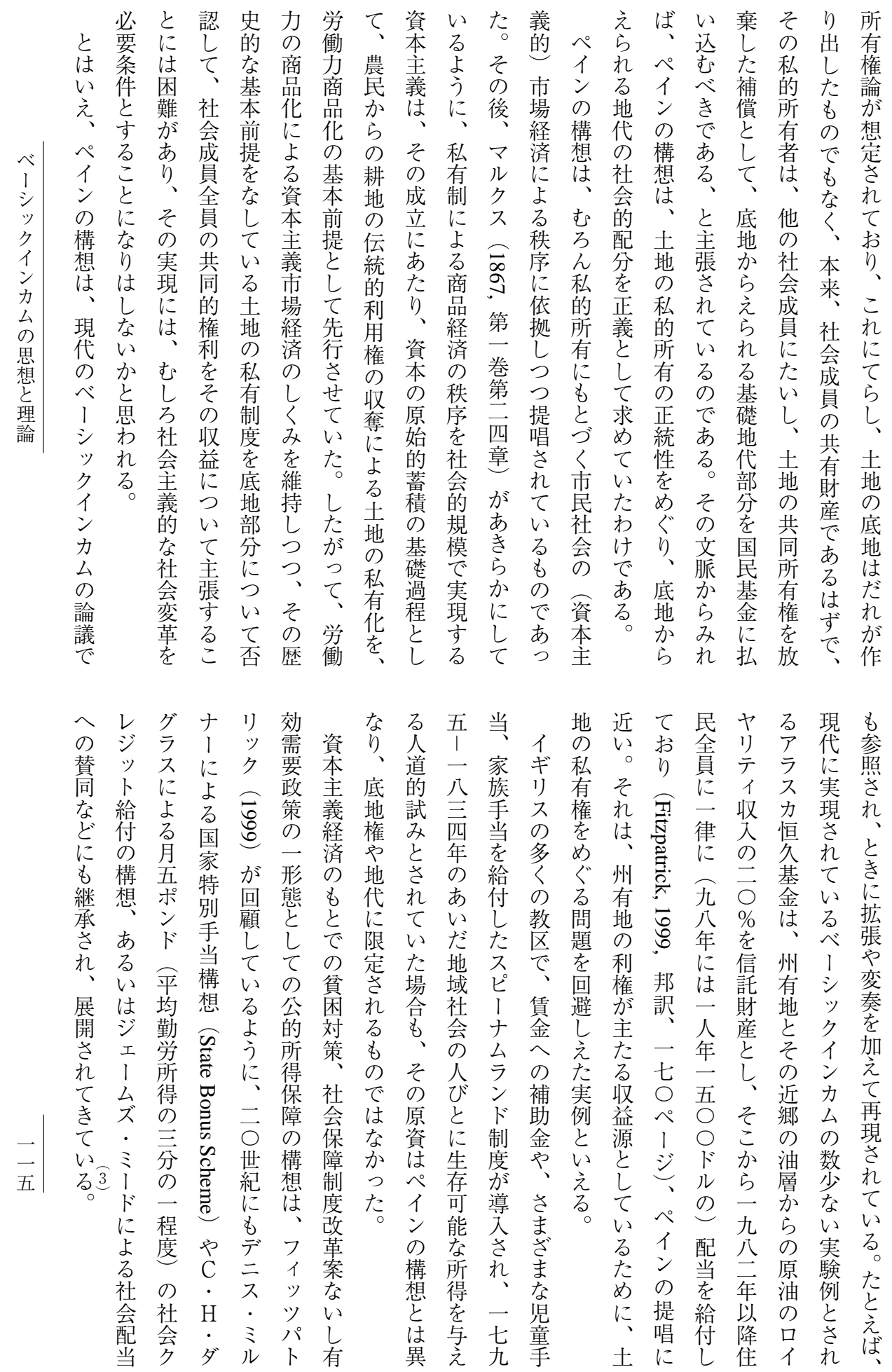




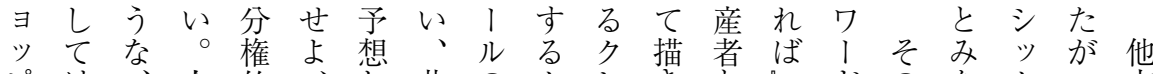

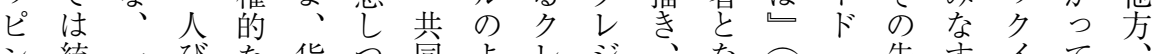

グ 統 合 種と な 企幣つ 体 う

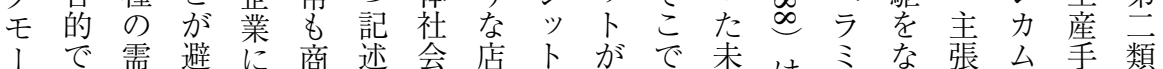

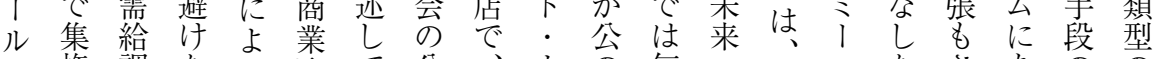

で権調たる取て 公、カ公毎こ私こたさあののの学

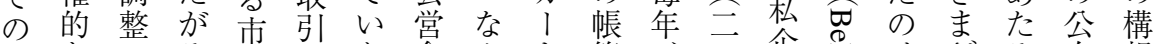

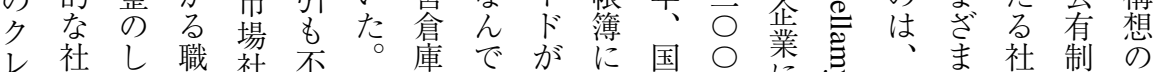

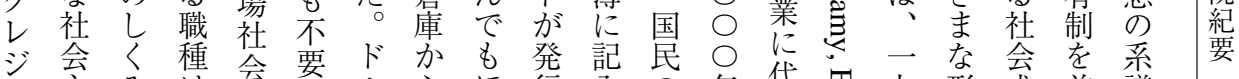

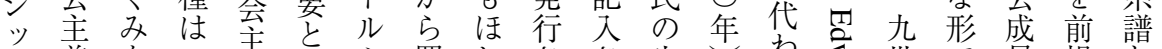

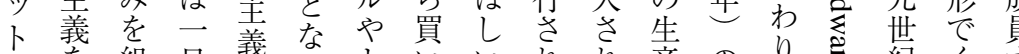

カ想 組 早義

省萣こ た

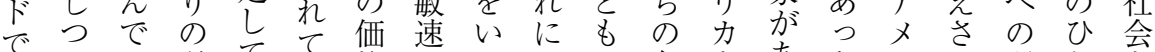

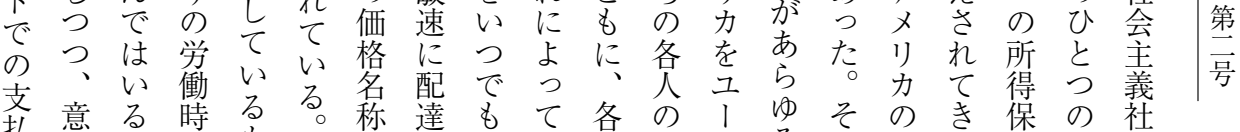

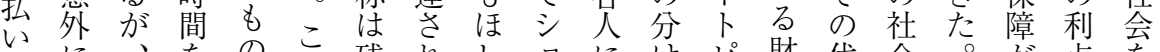

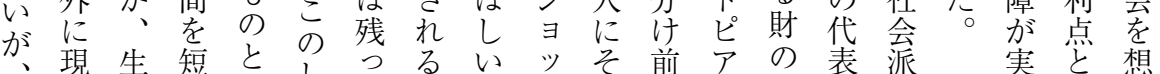

事代産 立

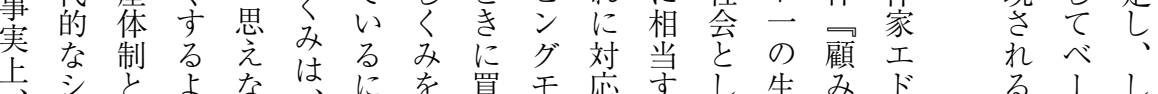

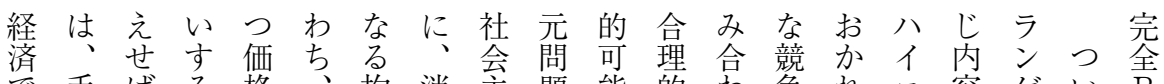
で手ばる格、均消主題能的わ争れ容ゲい $\mathrm{B}$ 実間、実表中衡費義も性経 せ市る クのの社

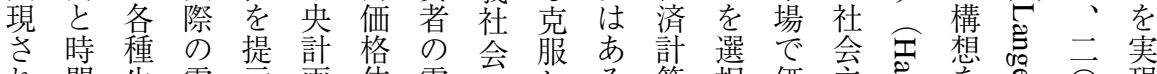

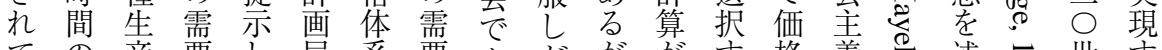

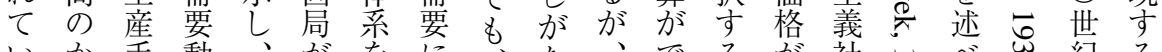

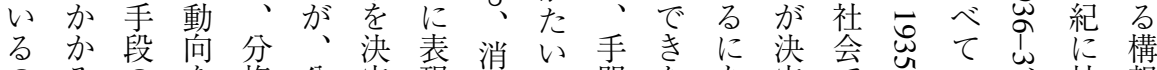

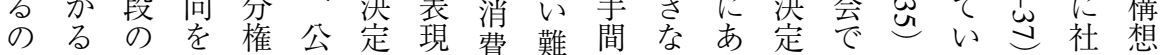

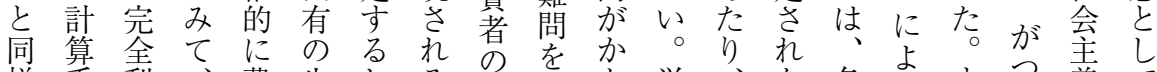

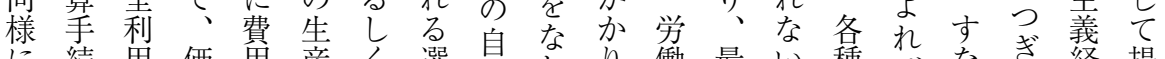

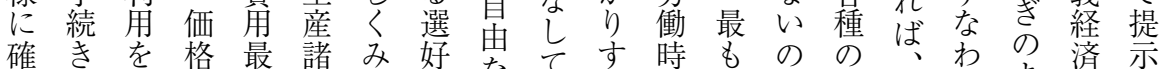
定を実表 経手を段つ生選い主間経で生生ち、方計さ

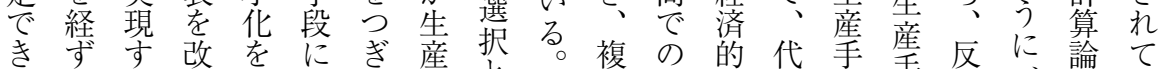
るにる訂図需の方と雑経な替段手段社へ争い

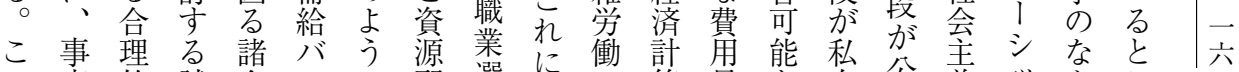
の実的試企ラに配選たの算最な有公義ツ少こ

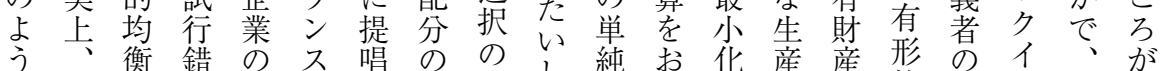

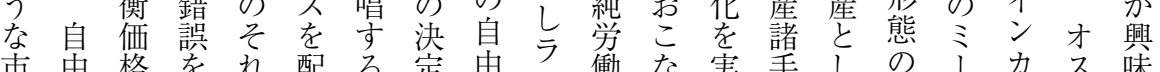

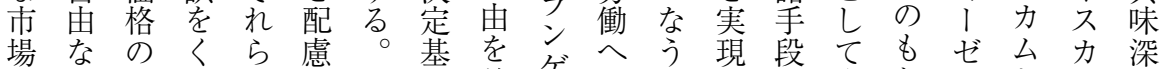
社市体り にししすす 準 前 は の 


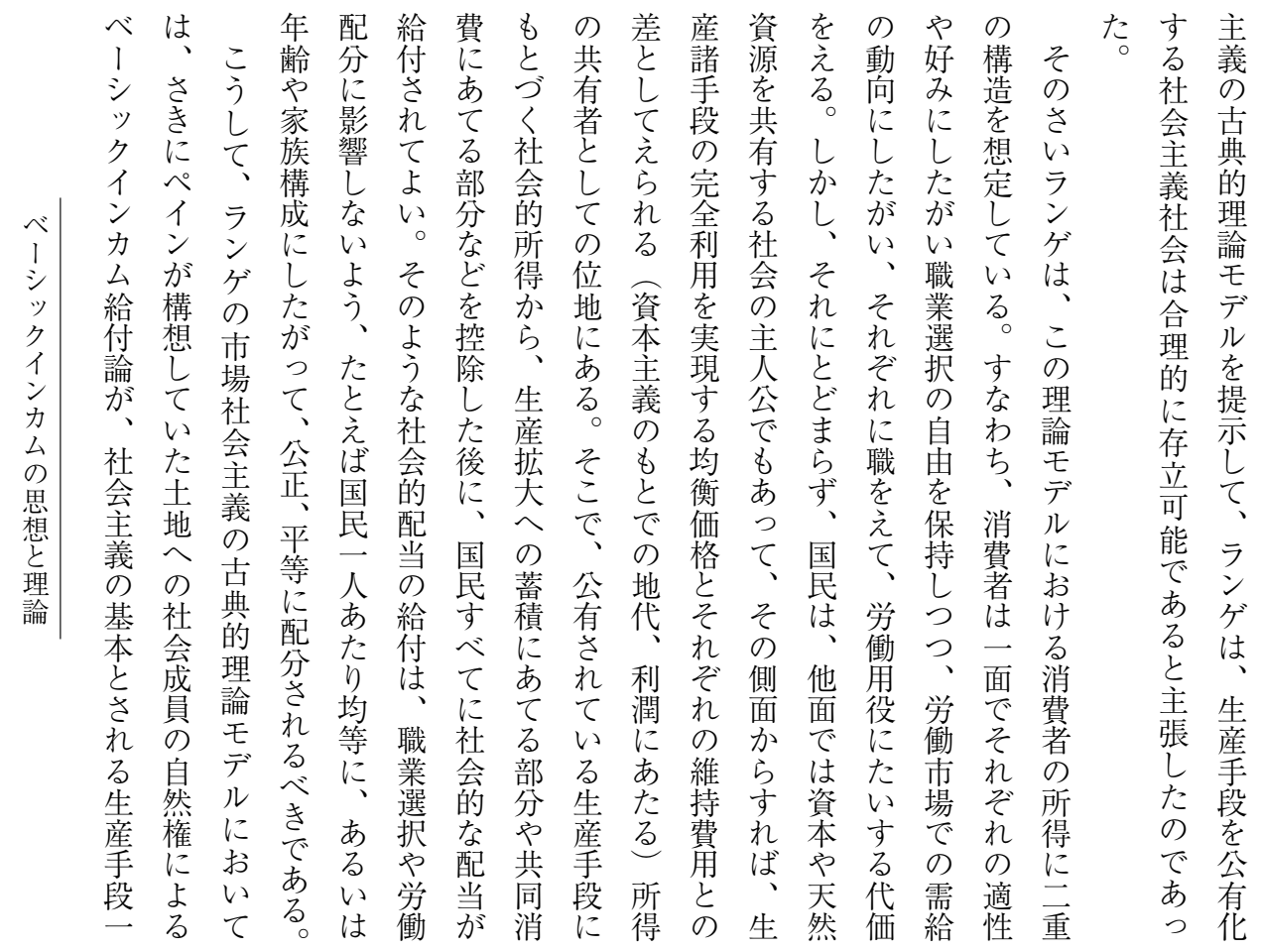

価おのに業をラのつ容れでたた介会主しの般 格そイ完選も主先て易は職といし的体あ公の 体れン 全択えゲ駆いに内をえす職配とた有公 系がセ $\mathrm{B}$ やるはとた、容離ばる当当みりに有 泟る る の。イ保配と費指りも年者内とい付れ成ら゙前 しそブ 障分想者摘、安!にのしる部て員く提

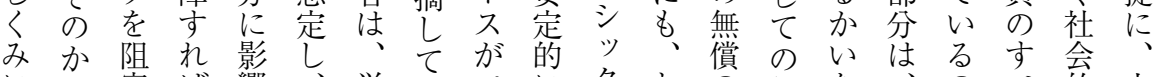

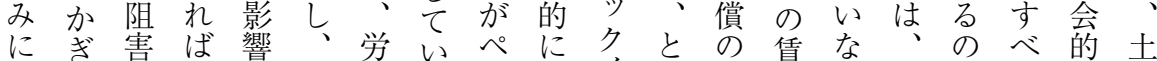
おりし、、し $\mathrm{B}$ 働る、イ実イううケ金い理でて配地

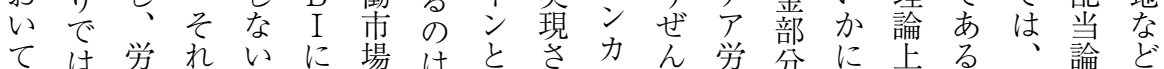
そは労れ れ働ら よ うラ市にうた需首ンやの給にえが市ら会論天 でン場影にる 給肯ゲす 構権従てわ場、の 理然 あゲの響と 社に艺をい想が事いら社生 主 整資

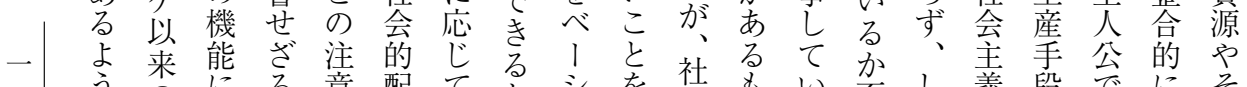

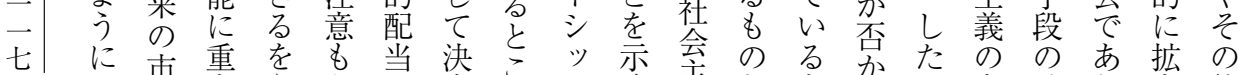
市重を学記当定

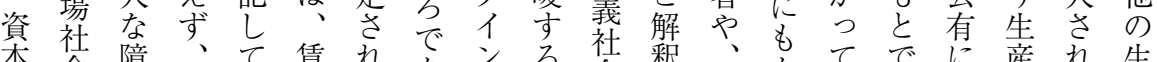
本 会害市い金 る

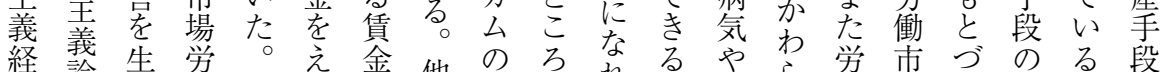

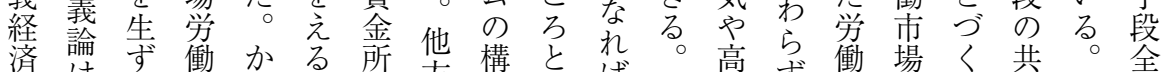

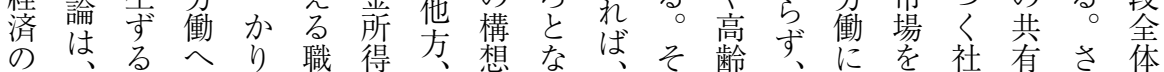


当態いと続 と 有 の

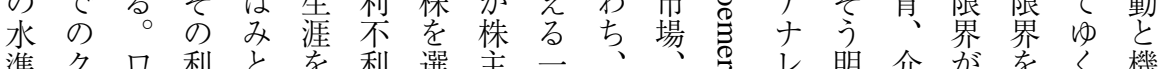

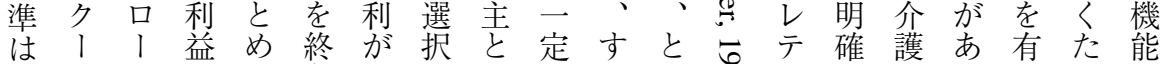

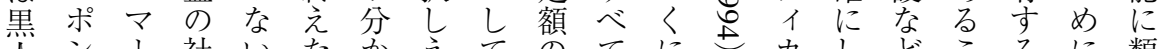

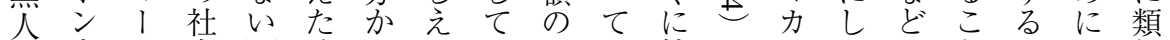
男市は会し時れたのクの株はルてによ゙似

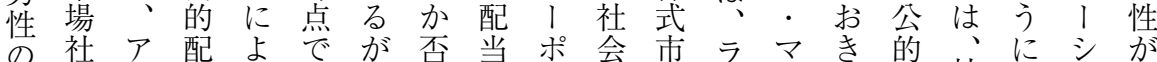
の 社ア 配よ

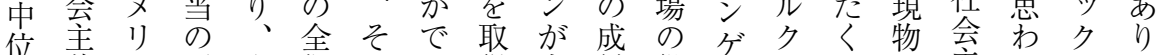
的義力平生保机、得支員役の 否な サ 主れ イ

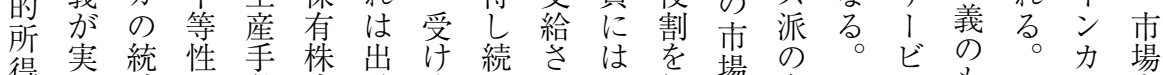
得実統 性 手 株 出

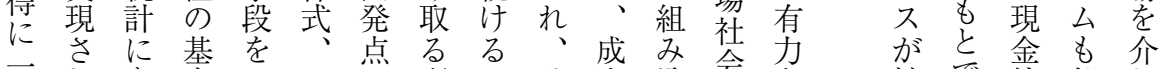

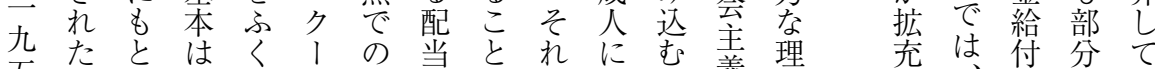

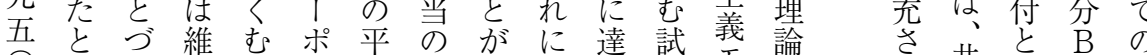

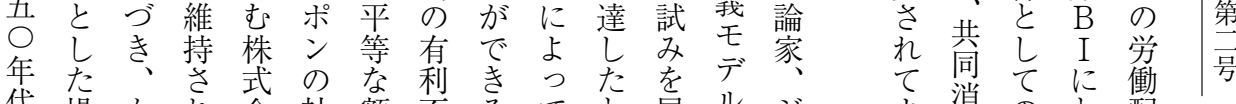
代場か的企社額不るてと展ルジ消のと配 で合りる業会の利。生き開を妇い費 B ど分 あ、にもものへクや成涯にし 現ン こ と

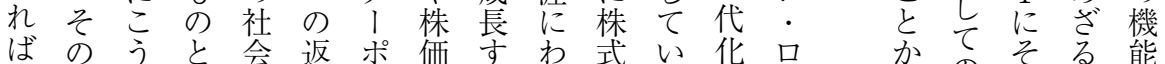

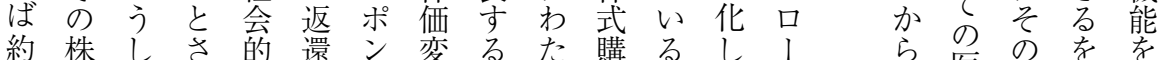

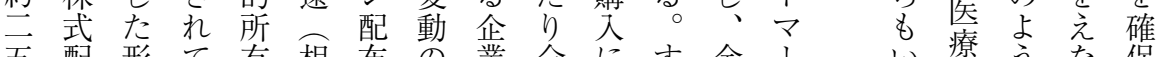

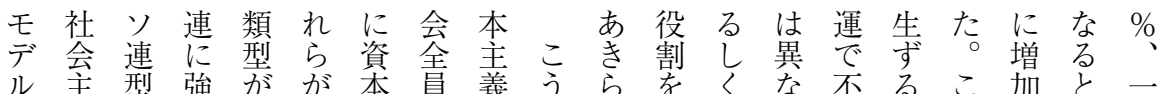
の義社い存容主へ市しか果みる均配のし推九 多、会興在 易 義の場てにたを社等当口計八 様分主味しにを経経み部す構会とは、所し ○

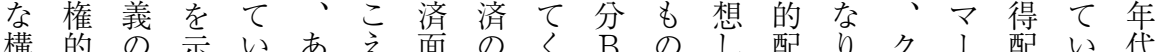
に会壊て。い社の内とにみいる理をを。る 活主後いそは会生で、とてる成がン論根しれ 発義、るの安主活、べどよ点人社でモ本たば なのむ欧両定義権社 | まい染に労各デ的がほ 研有し 米者的の会シる。達働自ルにつぼ 究力ろでのにも保的ッこしべしへがで変て二

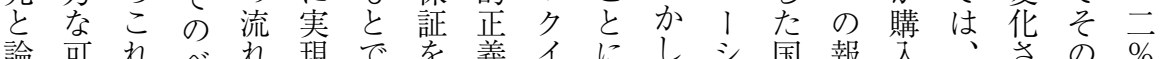

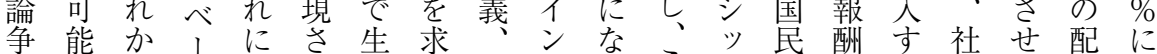
が性らシ配れ産め所力ろこク全なる 会る当あ

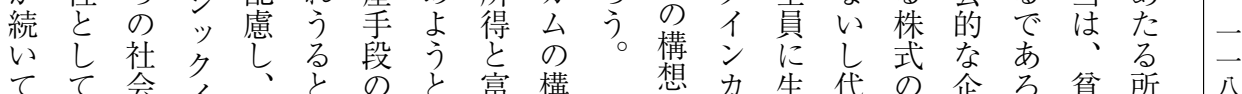

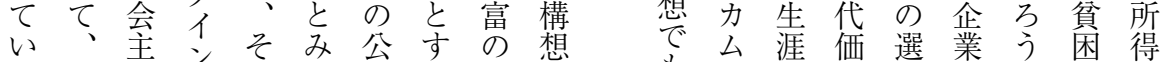

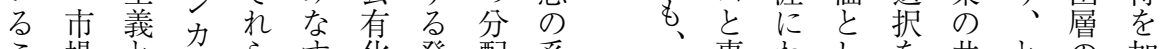
こ場と

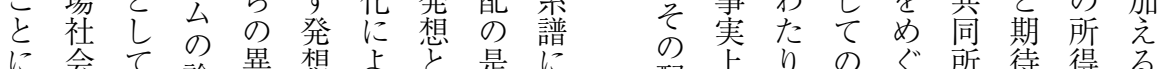

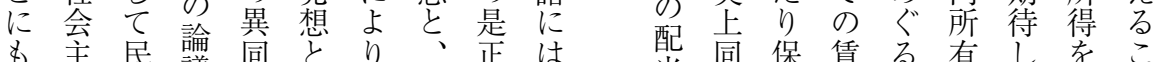

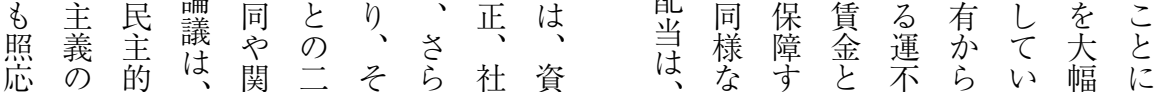




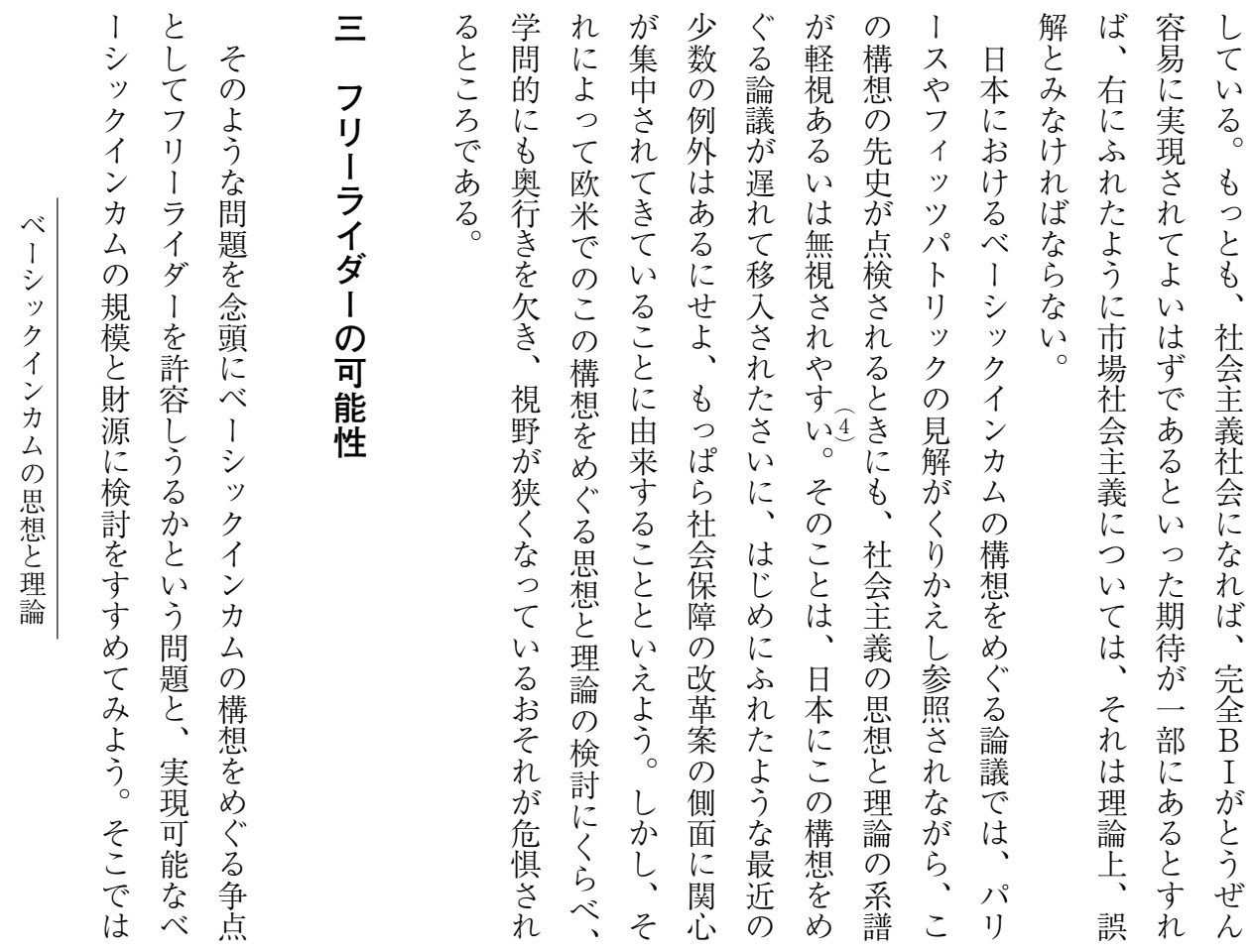

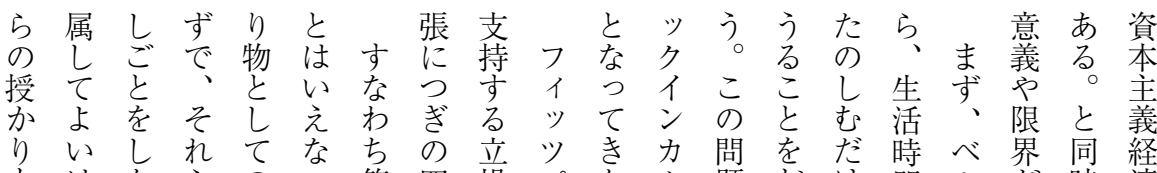

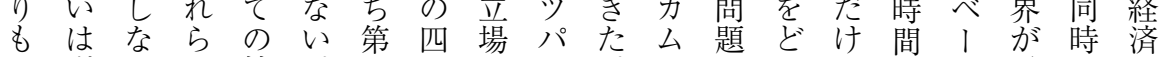

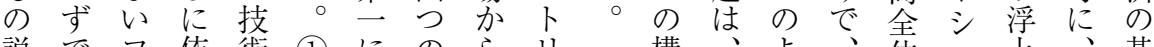

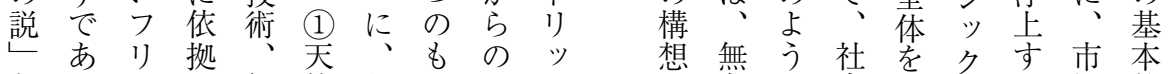
々る ででイ イ いッ、るはよのと再。律ら㸚間允を義の るツに所社う社し反第ももな給あた制

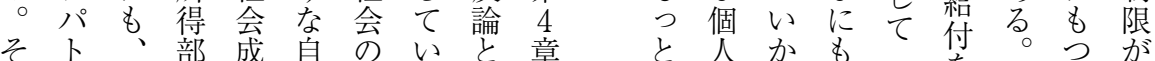
れリべ分員然所 る

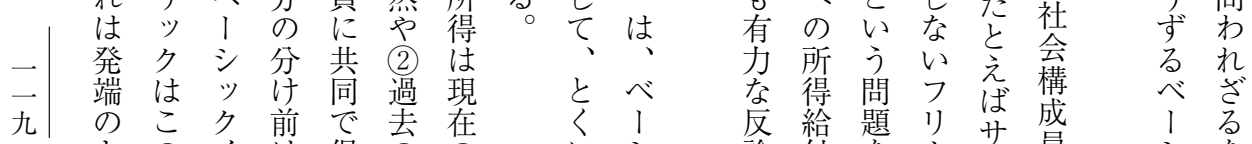

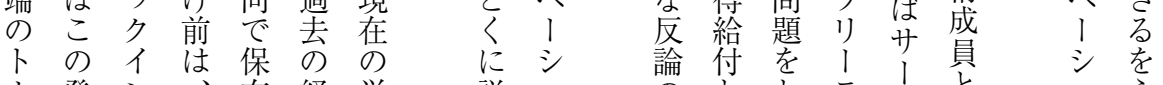

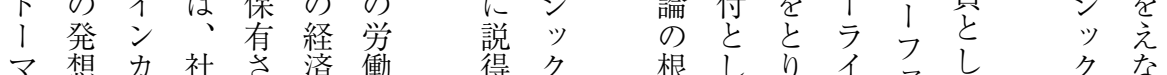

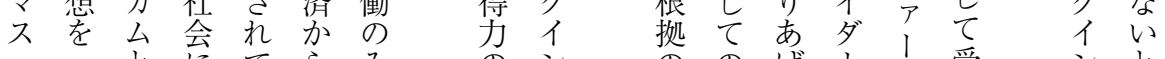

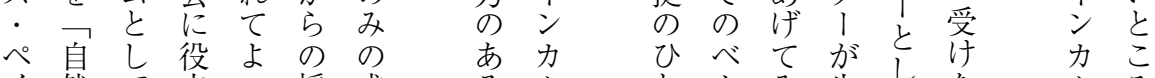
イ 然て 立い授成 


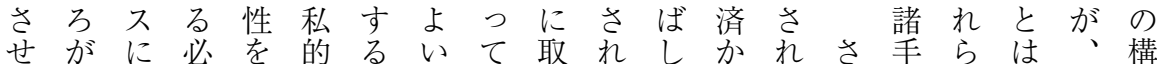

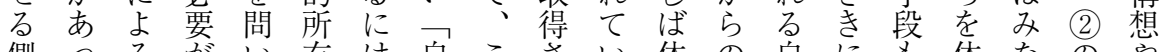

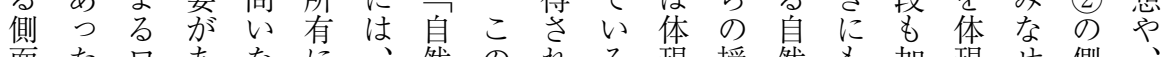
面た 只

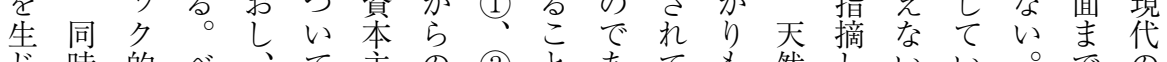
じ時的べ、て 主 の (2) と あ て

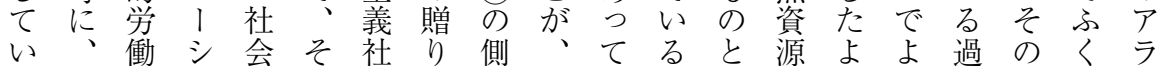

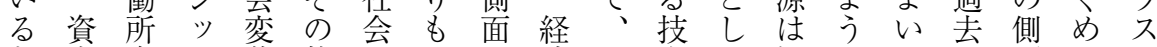
之本有ク革 特のの済そ術て概にのの面るる力

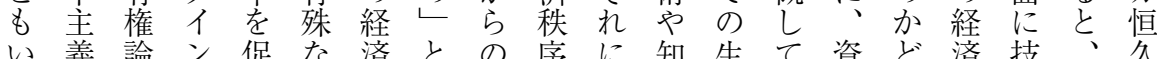

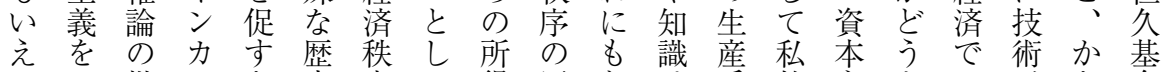
るこ批台な史序て得原とは手的主加の阵な金

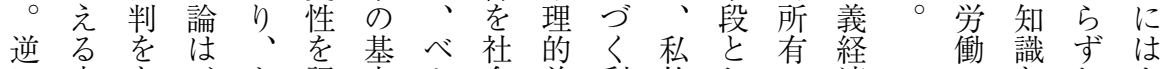

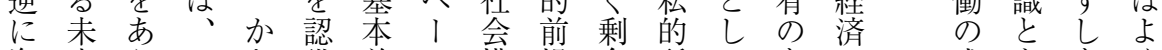
資 来らこ社た の 主会め問のた省な值と存にい然市

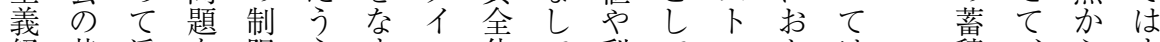
経基浮を限え す ン 体て 利てッかは積、ら

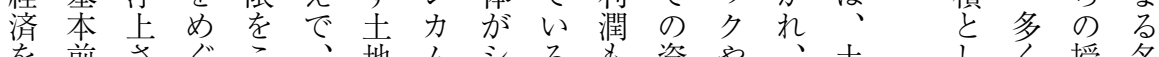
前 提 せ 提をるマにの資基アししたに去に楊りで

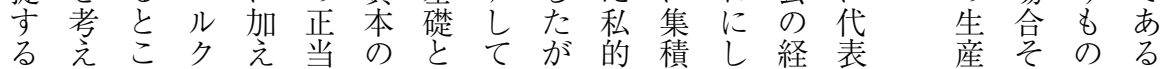

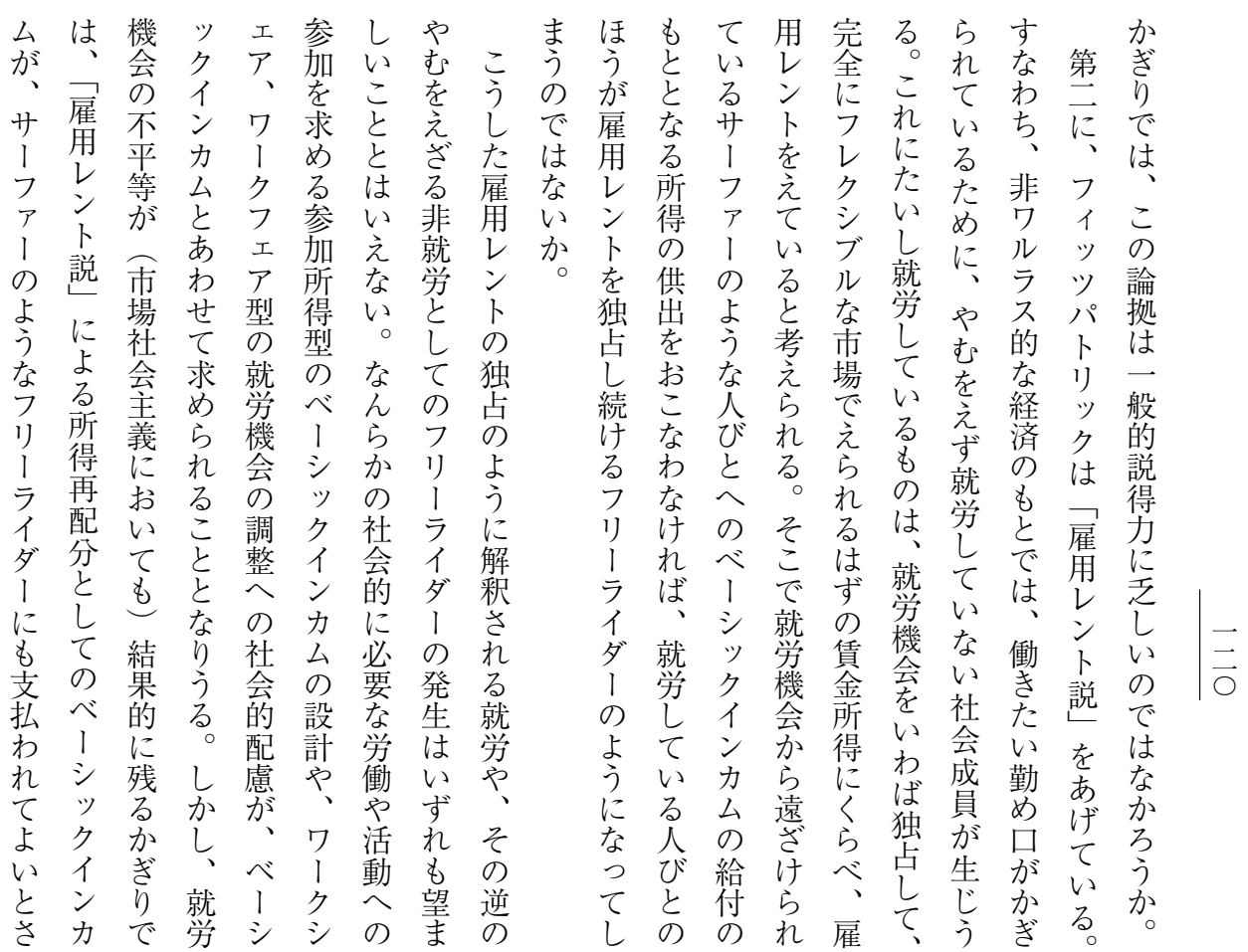




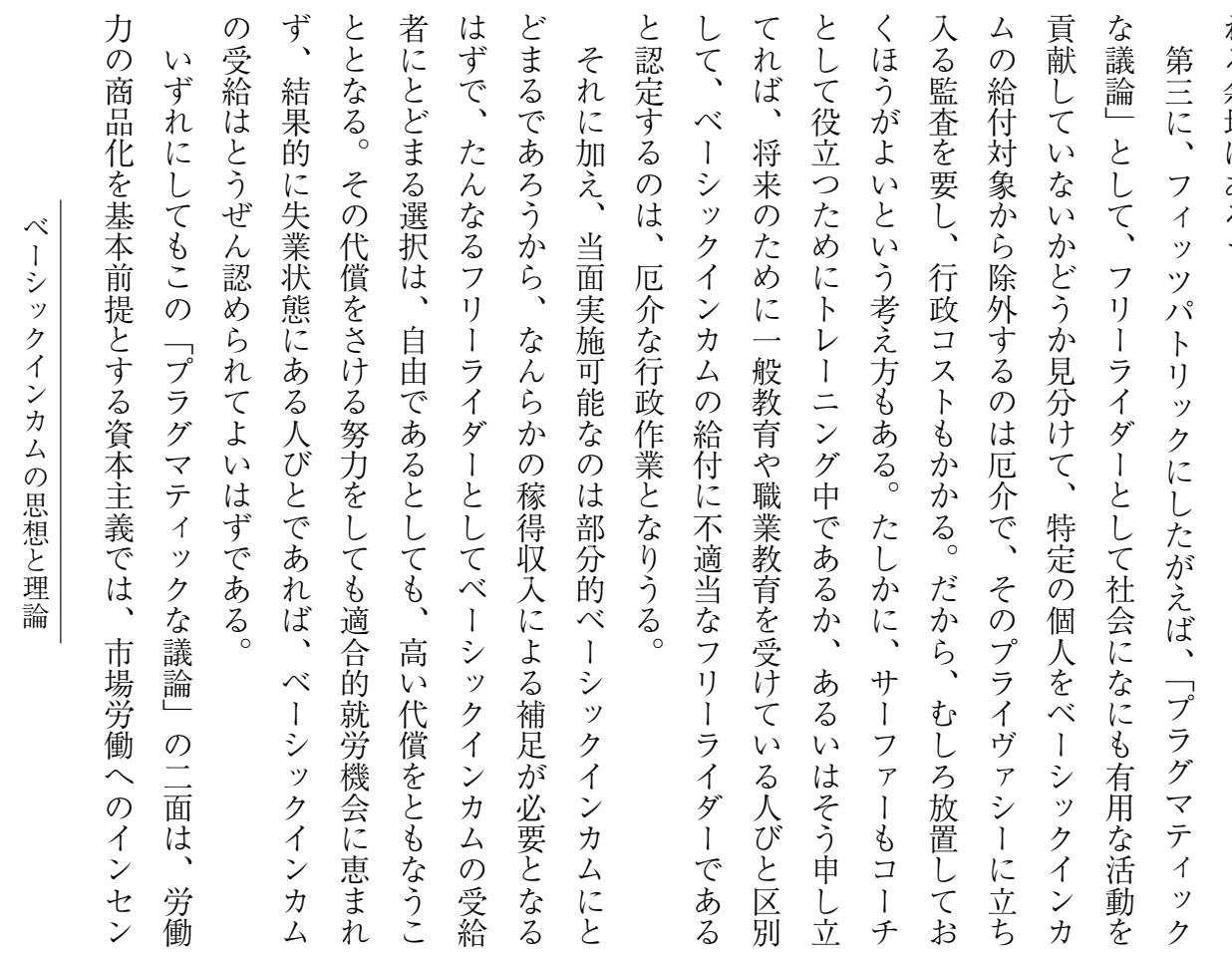

と様た関い。想なも奇 の

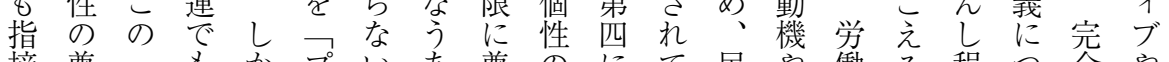
摘尊马专かプいあ尊のにて民や働る程つ全や

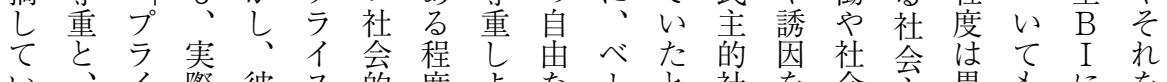
い、イ際彼入的度よな1と社を会主異もにを る互入には多代のう発シも会保的義な同到介

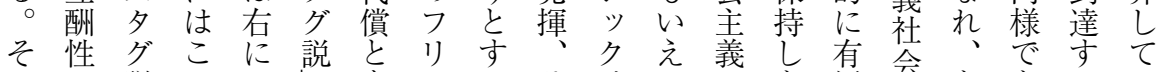

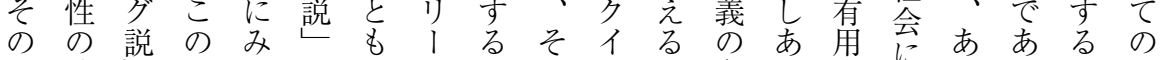

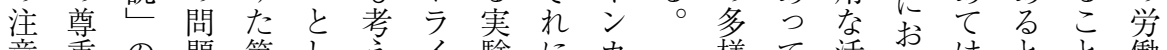
意重の題第しえイ験にカ様て活的はとと働

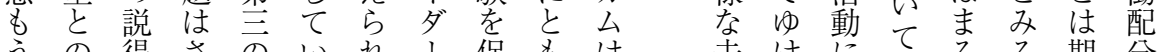
うの得さあいれ、促もはけにてるる期分 な両力ほ二るるのしな本来る個十も待の

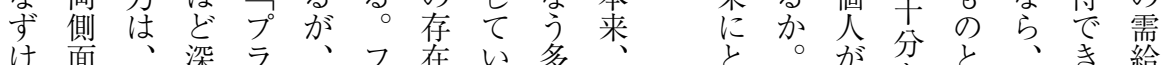

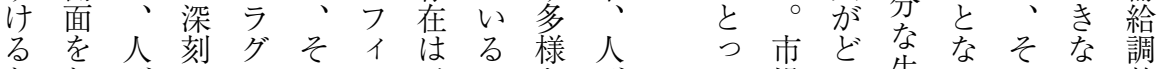

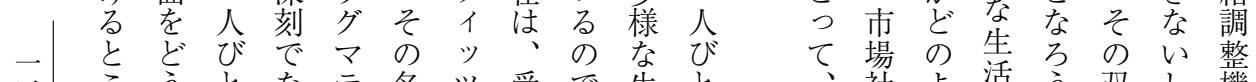

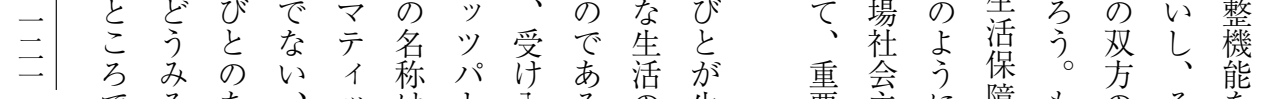
でるあ、ッは卜入るの生要主に障ものそを

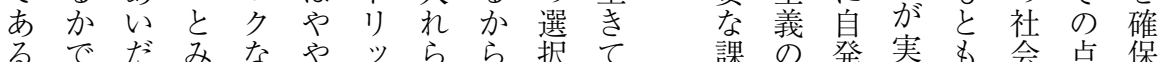
。変のて議わク机、のゆ題可的現と范尔 そわ個い論かはなそ自く唯能にさ資久市る のり性る唡りこけれ宁市性参れ本テ場た

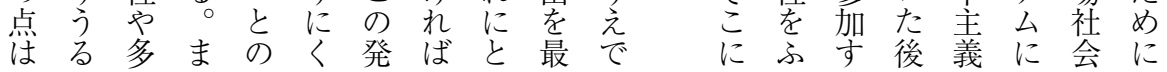



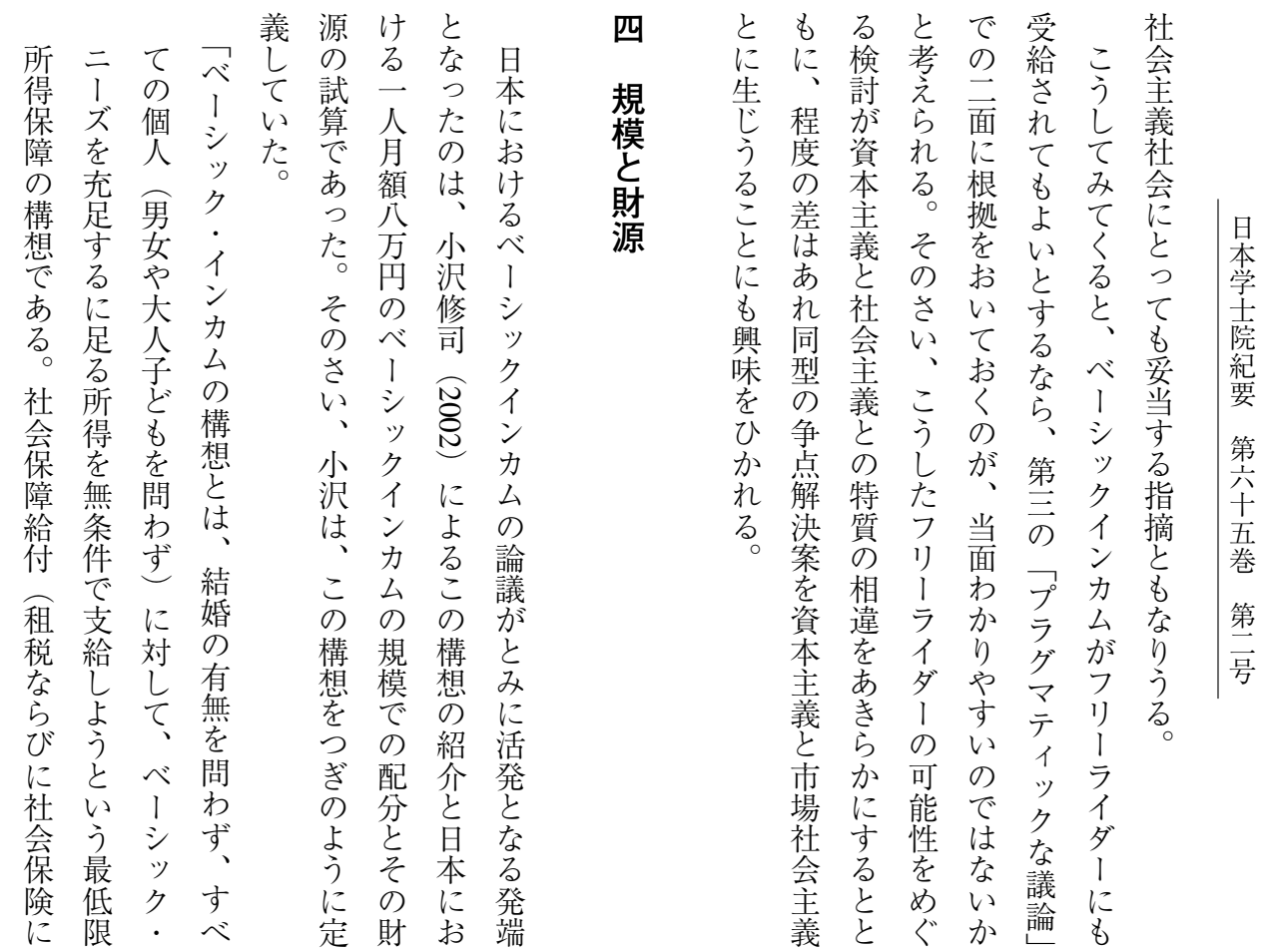

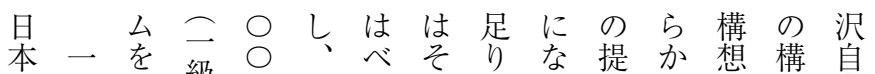

の 本を 級円 生

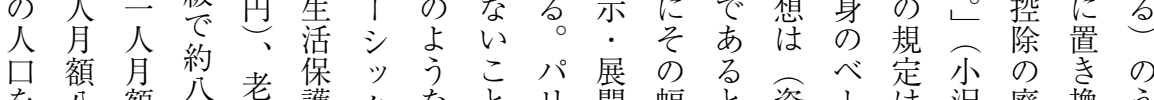

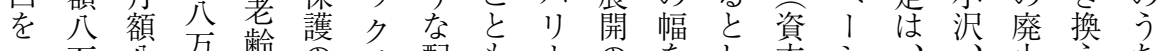

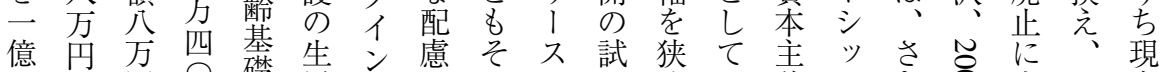

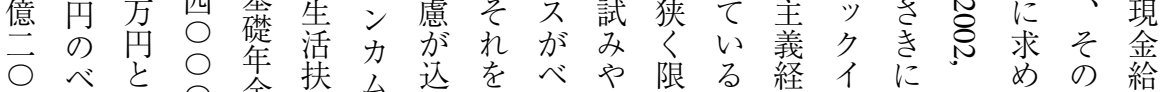

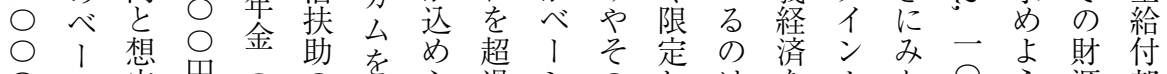

方定円蓒 の

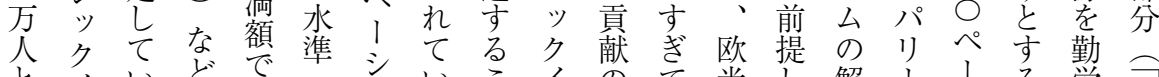

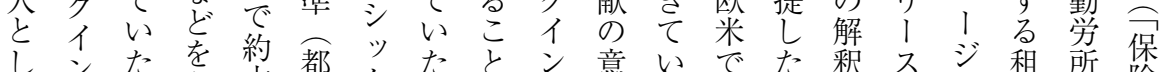

て カ た 参六都ク た と

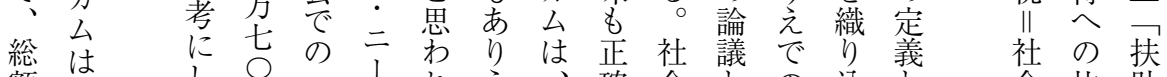

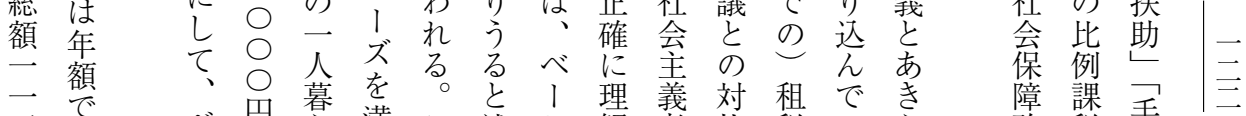

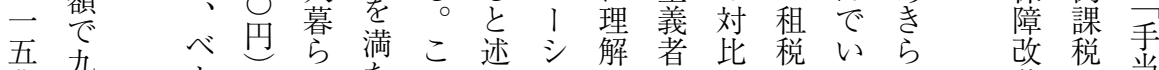

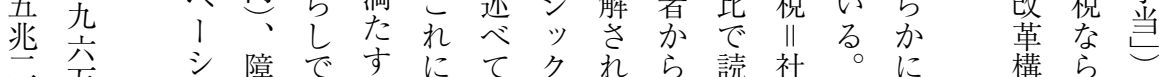

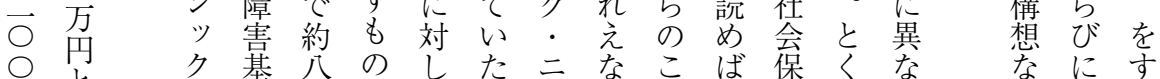

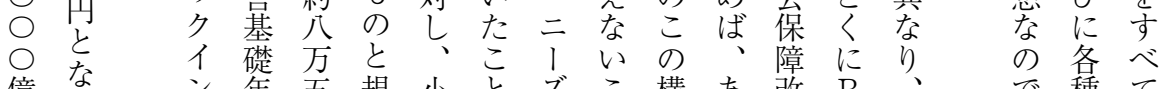

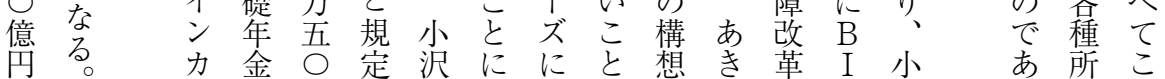




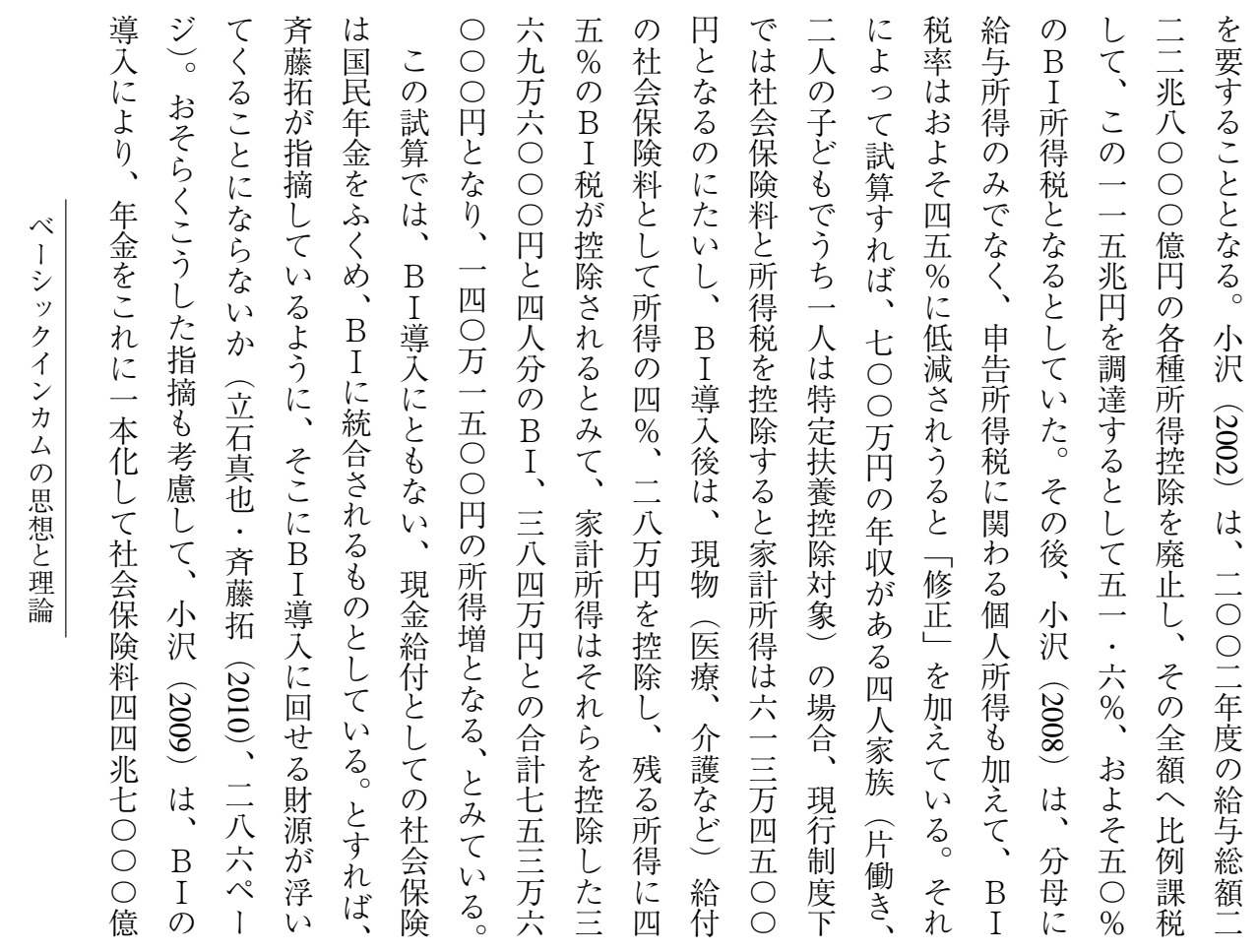

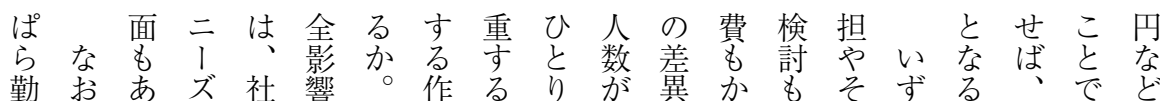

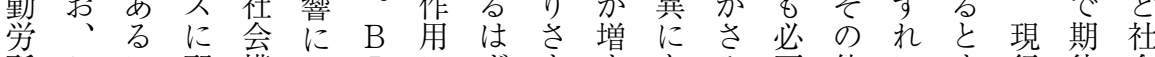

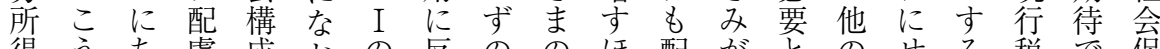
得うち慮成おの反ののほ配がとのせる税で保 へしがし員幾規転 B 老ど慮ちな公よ構制き障 のたいたに箽模す I 後、をなら的、想のるの

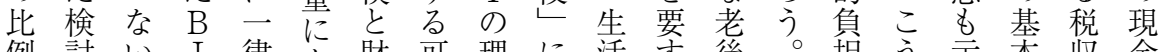
侈討

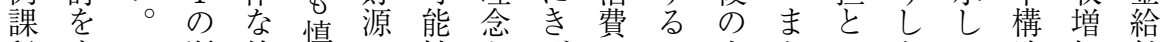
税す漸給重の性がびにの生たのたて造加付

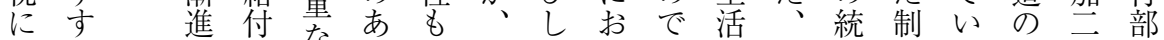
求め的と梌心方現いけはに追合度るも尾分 めるなし検関く実制るな不加関設。と兆約 て制な討連んに度規か安的係計染向和 いい度いを要しではに模ろを労でにも余○ る、設、要たい家なのう生衝のざ的兆

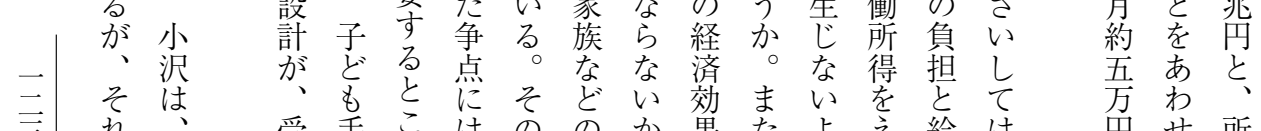
れ、受手こはののか果たよ方給は向也所 は $\mathrm{B}$ 当ろ点共。出家うに付、のて得

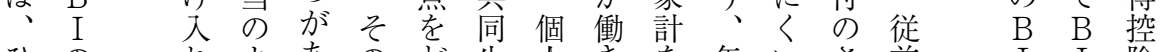
ひのれよあのぞ生人きをを年いさ前 I I 除

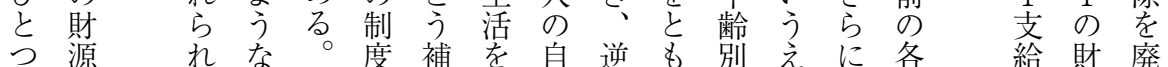

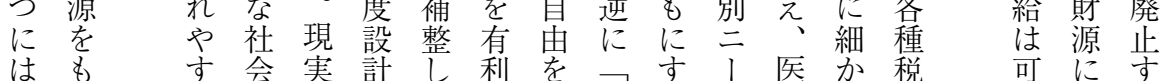

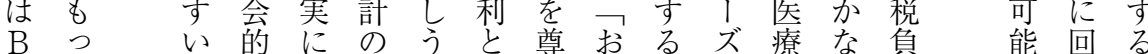




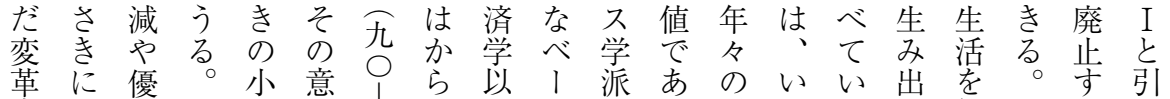
案も遇村沢味二ず降シのるる労わるる維しるき

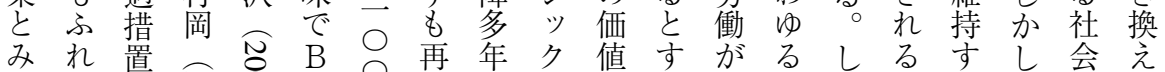

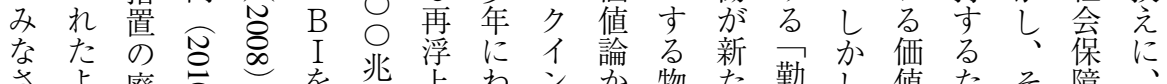

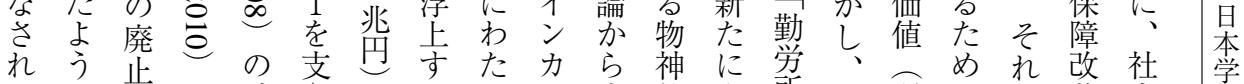
るに なの 試え

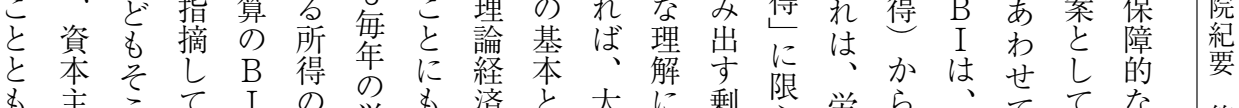
な 義こ

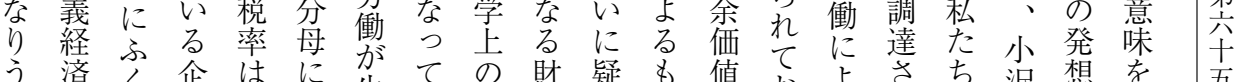

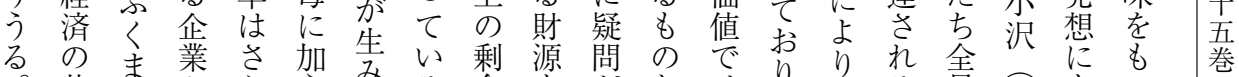

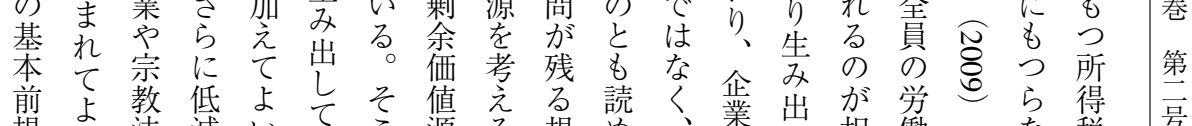

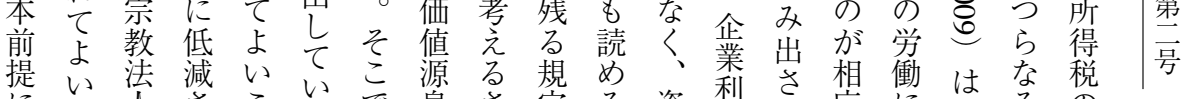

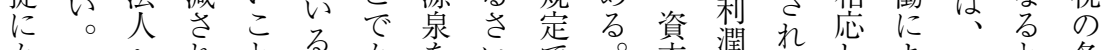
かっ れと新かをいで。本潤れるしょると各

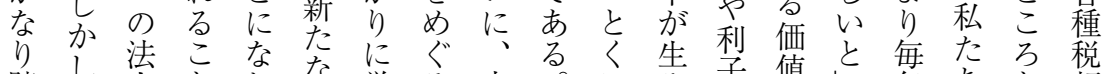

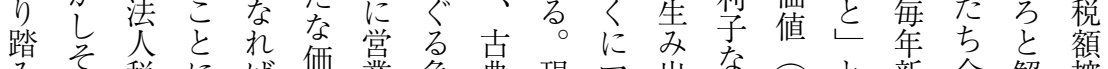

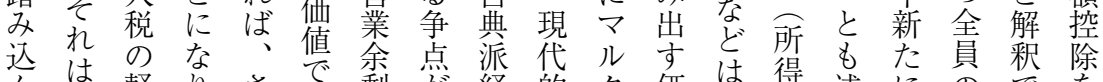
んは、軽りさざ剰㤎経的ク価は得述に貝整

れみ力が現のにと済な $\mathrm{B}$ で給はれ給約と

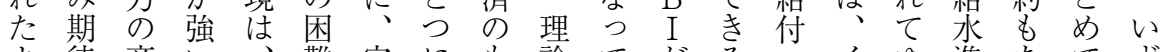
よ待商い、難完にも論て がる

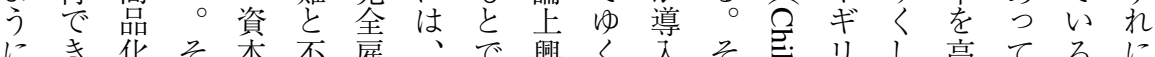

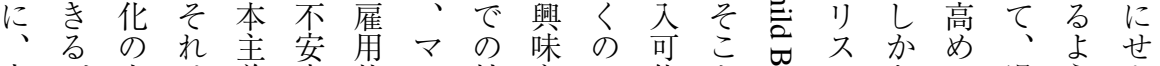

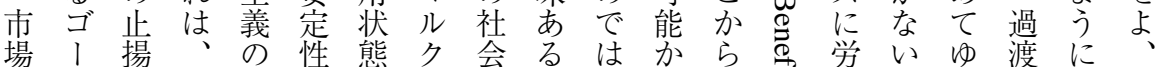
社ルに事もを古不保問などつき働でく的、フ

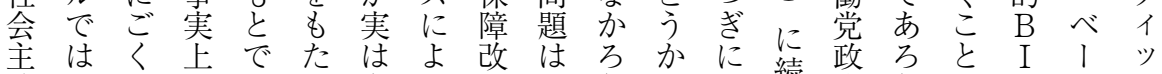

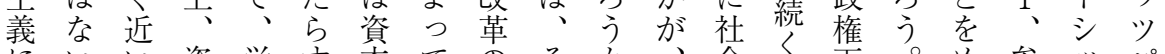

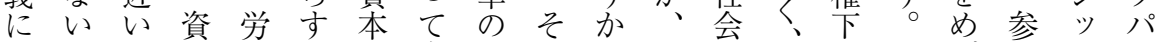
おかも本働こ主宇枠の。そ成過で日ざ加クト いとの主市と義野内少少過二本し、所イ リ て考で義場か経学でき規す渡九で、得ン、

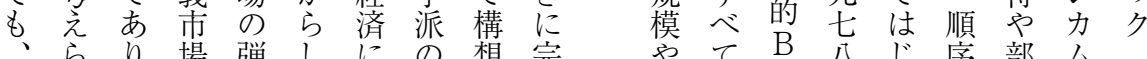
完れ 、経 弾 し 全る社済的も慌き $\mathrm{B}$ 源無 の 七 5 第 $\mathrm{B}$ 導 も

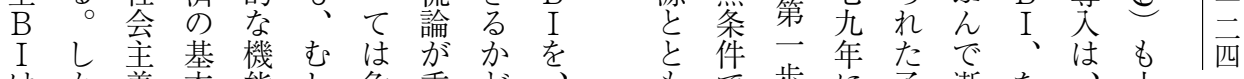

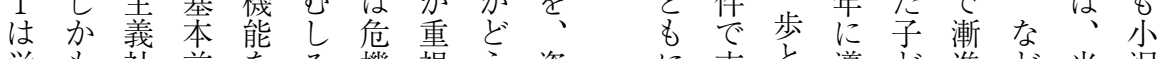

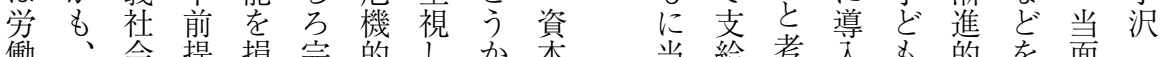

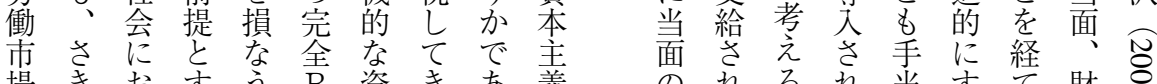

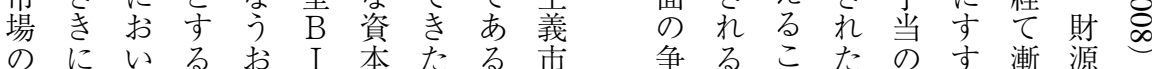
のに調も て る 整ふの働れ実積うひ経学分が童給ら支制み 


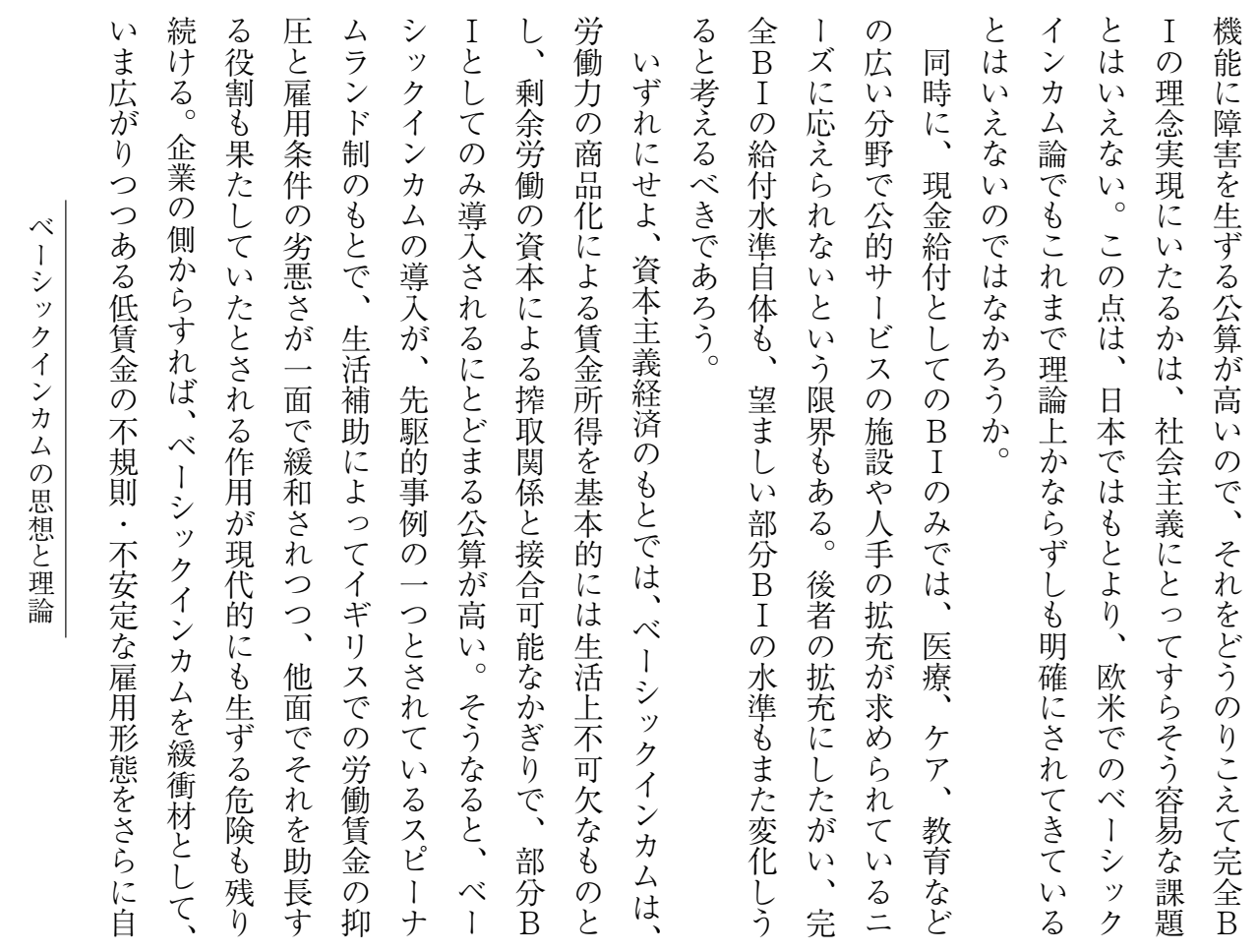


想势ににク ら

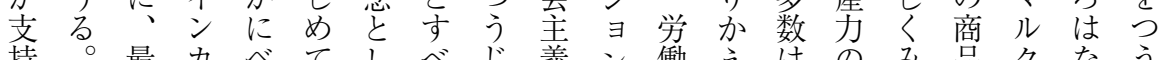
持。最力べてじ義ン働えはのみ品クなう

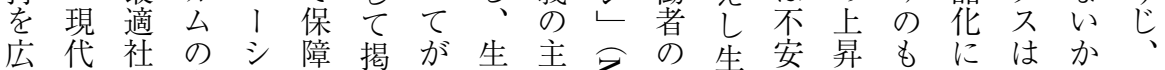

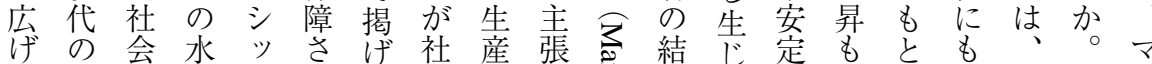

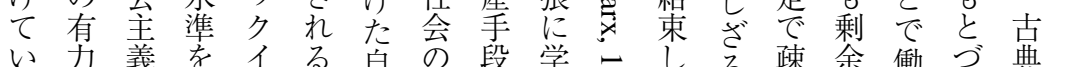

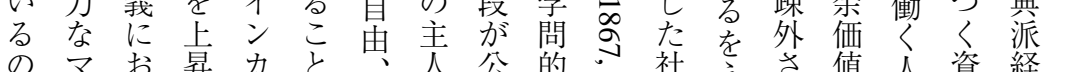
は等公公公的経

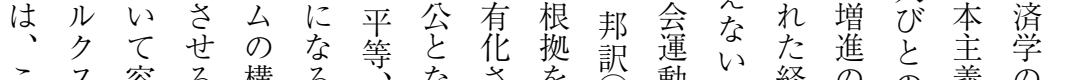
こ

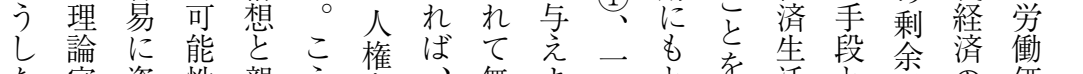
た諭資性親う権 ば

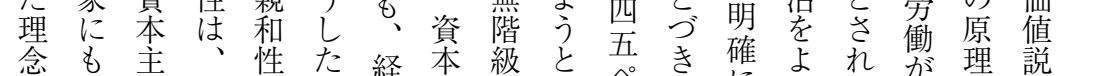

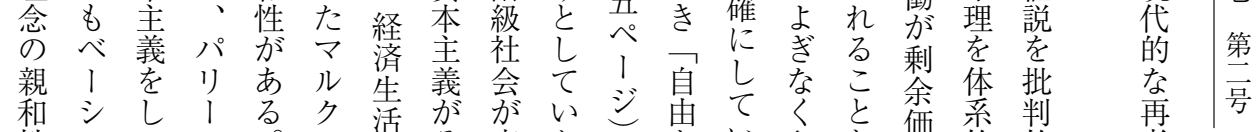
性ッのス。㸃々実たにないさと䡩的的考

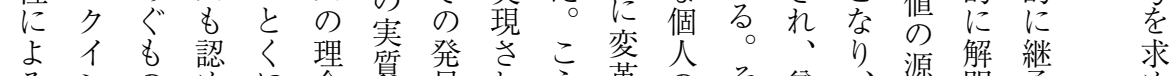

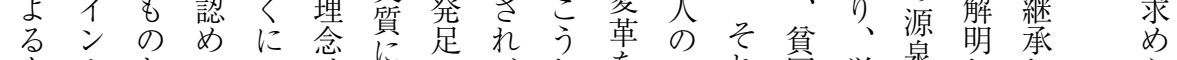

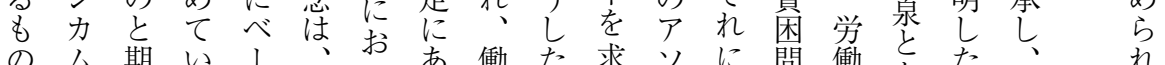

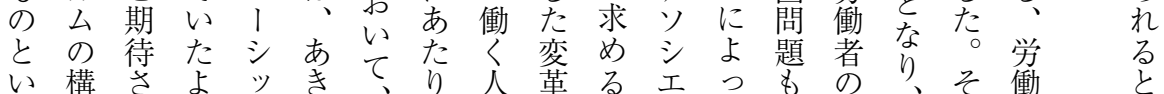

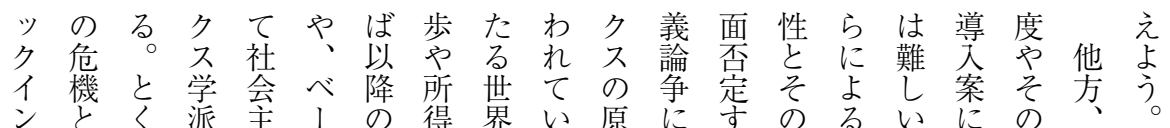

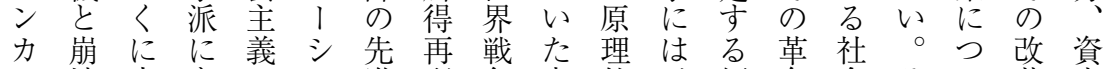
厶壞官もへッ進配争点的、傾命会そい革本 のの僚あのク資分やに規資向的民こて案主 構過主ら進イ本が大問定本が娈ではと義

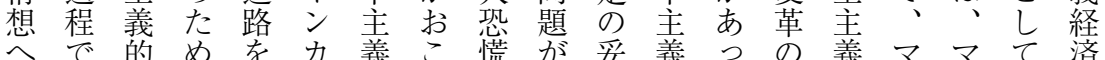
の、なて展公諸なの当な当のた方的ルルのを 支欧集有望に国わ危つ性新。針改ククべ前

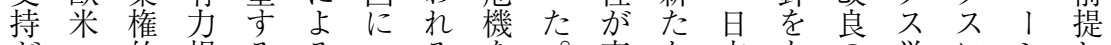

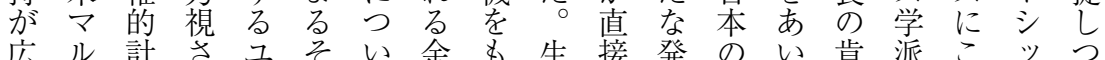
がク画れ门のて地経産一展宇ま定のれクつ

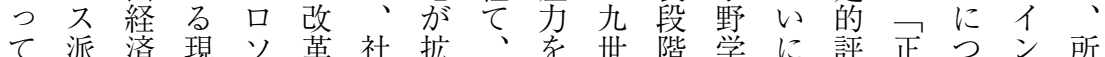
きのに実 シ案会大労格紀論派す価統う力得 て理依的アを保さ働段末 のかるに派ず允再

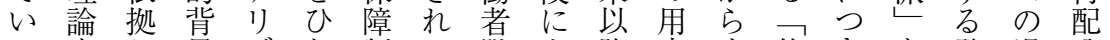
る蒙し景ズと制て階上降意守修きも発過分 のた少台つ度き級昇のをれ正、心想渡に そなり広のののたにさ時欠ば主資ルを的よ のか連㤎発不云もせ代く義本ンみなる

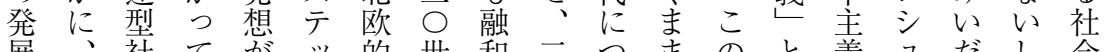

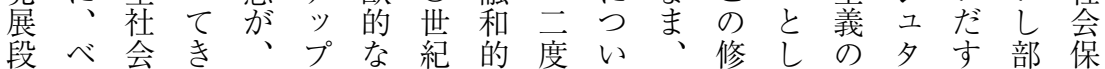
諧 


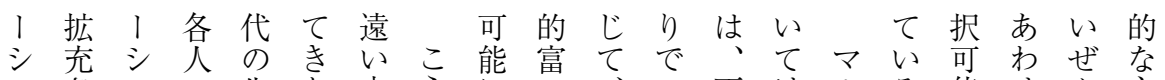

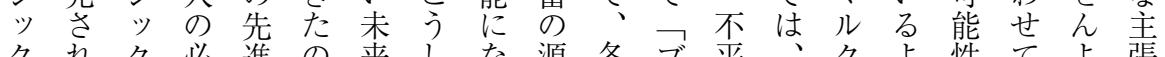

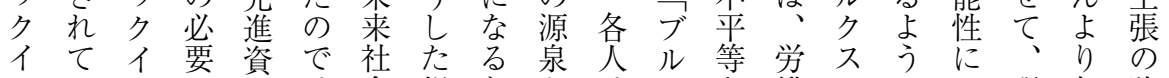

ンゆンに本は会規と怔はジな働つにつ現急論

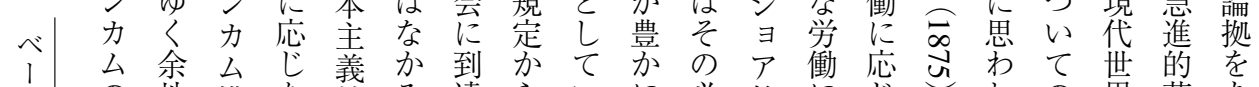

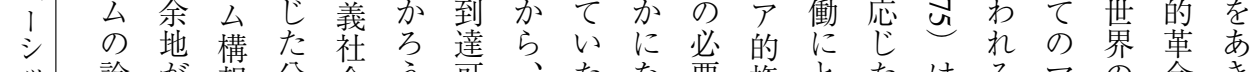

ク 論 が想 分 会 う

イををる

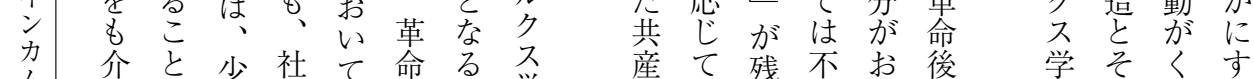

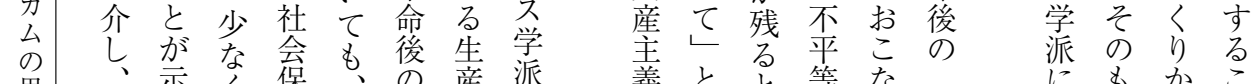

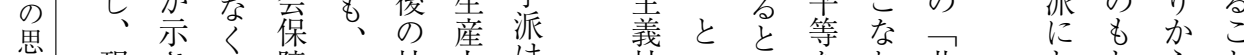

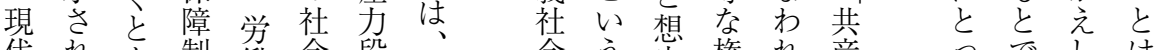

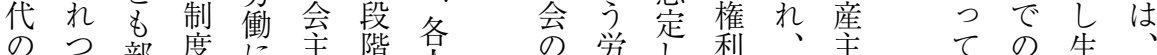

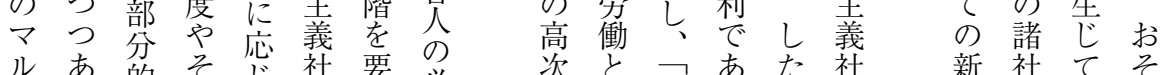

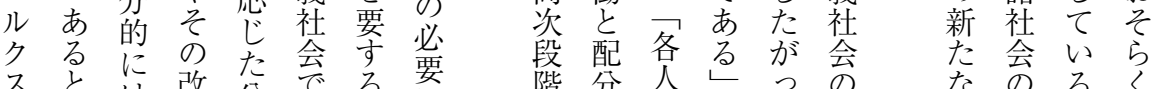

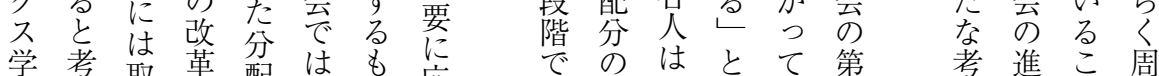

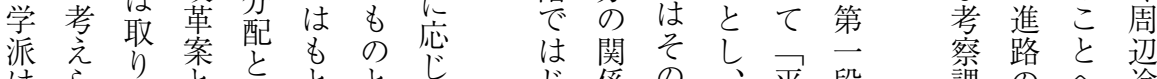

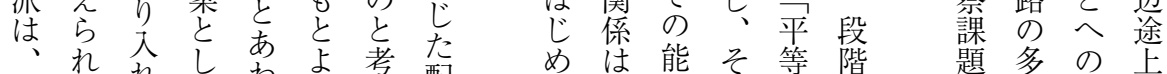

マる る れ

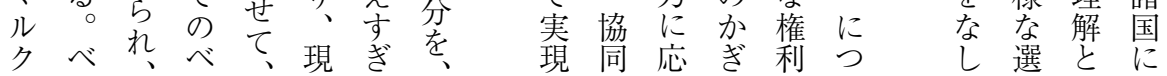

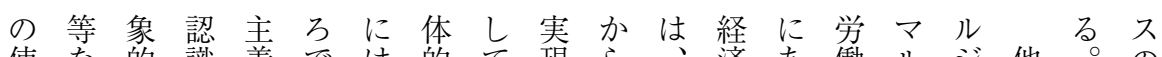

使な的識義では的て現ら済あ働ルジ他。の

用社人 に

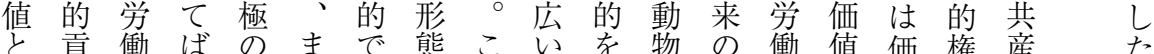

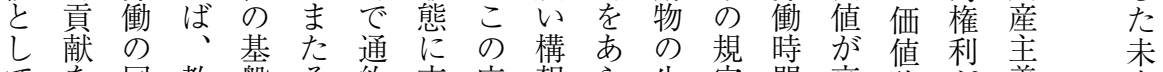

てを同教盤そ約支広想ら生定間高論 が義来

そた的や求に能出人実じ維残生、拈る 低 社

のしな訓め人なれ間行め持し産そいいる、资 な

労て 支 練 る

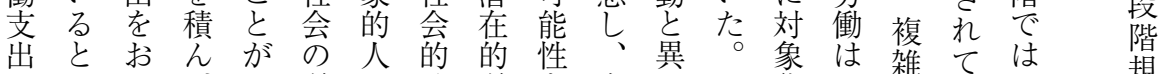

がみこだ学間分学を合なし化お椎て的学

同なな複き働労業働共貝り、かすな学い䡃た労

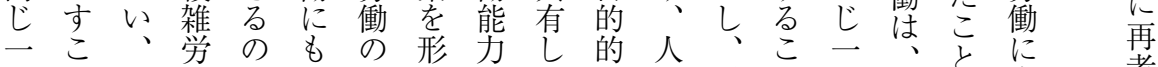

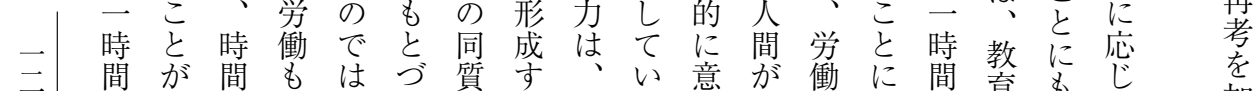

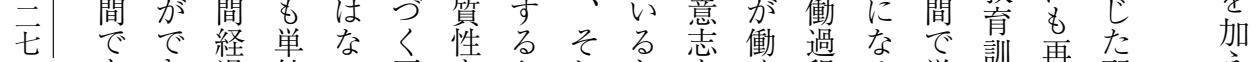
单る に過純 い 平学 か 等 支 い

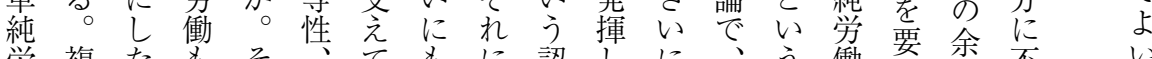

労複たもそ、てもに認しに、う㗢守余不地い

働雑 が と

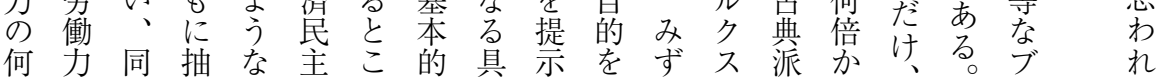




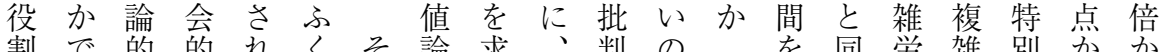

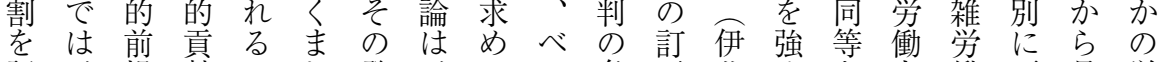
認、提献 ベれ発、る! 多正藤めな力働 要 是労

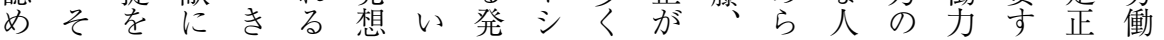
られ整つもケはつ想ツは許もれ間使のるるし実 れら芝いのアまそに理容吊た労用再教た体

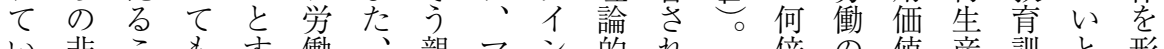
い非こも方働、親マンン的れっ倍の值産訓と形

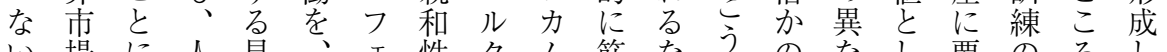

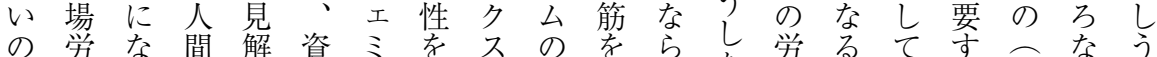
で働る的に本二増の構とばた働有のる労ののる紀 あはで労批主 ス昌労想お価時用労価働でと

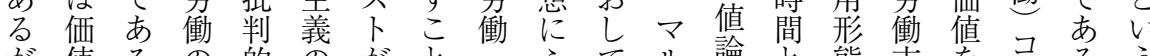
が值 う 社会余資的 峙で調 な 産 ま 的価本関し の て う 程 る う 值 ル 生鏟義性広場た や告済認非働事机活にぐ複なな純るに学は定 そもの 識市と 労 た の し し し 場 異働 め して 二のな理社別に価障時の扱い時れ複ば観

問こ完展力さ則殊と程に的なをで場識べ !

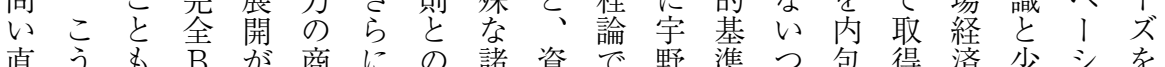
寸し興 I 、品さ理形本扱学亡つ草しさになッ満 こた味の資化き論態主わ派し社、机組くクた

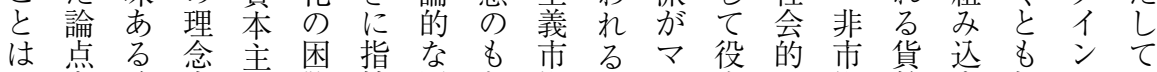
を論実義難摘区と場諸ル立に場幣ま相力ゆ マふ点現のに別に経社クて維栄所れ反厶く

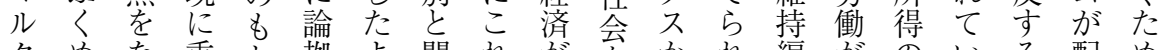
クめな重と拠よ関れが唋かれ編がのいる 配め ス、し大でをう連を労つらて成ど社るも分に のベてなはおにが組働う読よ学の会がのざは 思! い 想シ る 理 ひりル主点包品済てとくそがのら想

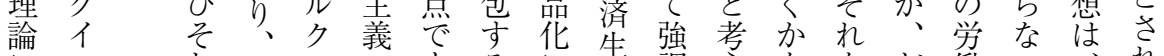

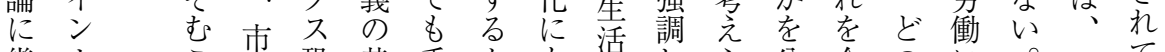

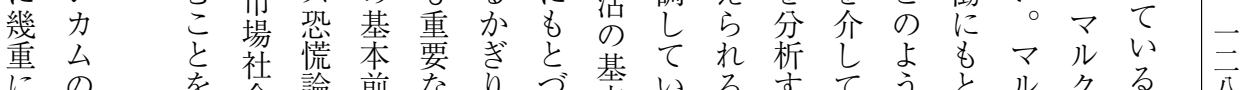

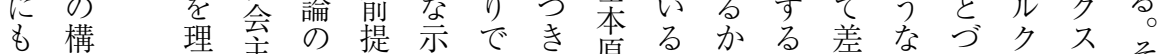
現想論義宇と唆示、則、らた別意きス価々 代と的我野しを学市則労でめや味資価值担 的のにも学て 与れ場経働 あに抑で本值論担 な親示再和 哌

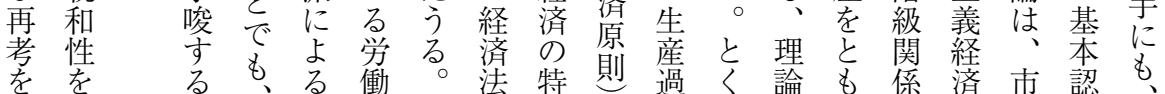




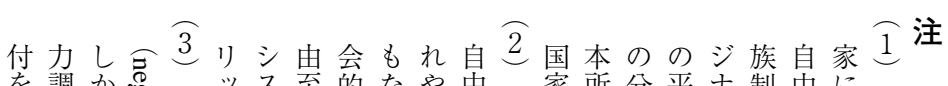

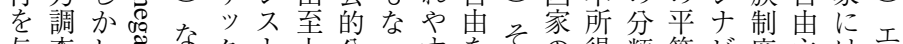

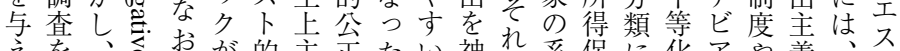

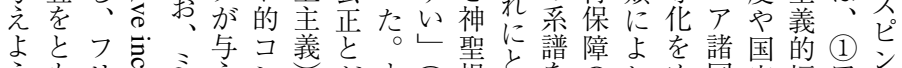

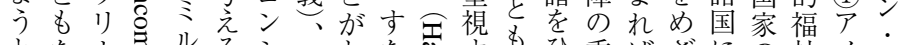

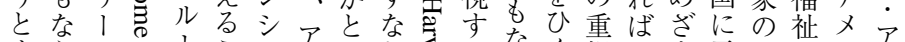

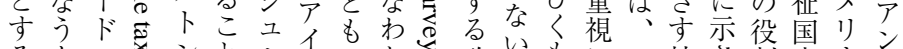

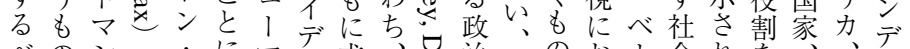
ベのンのうにマン求、治 D の打! 会れを机、ル

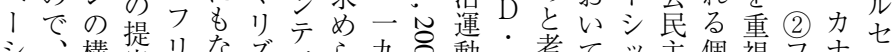

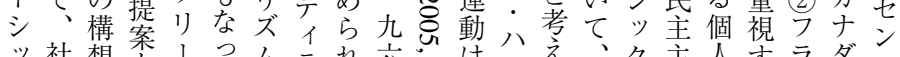

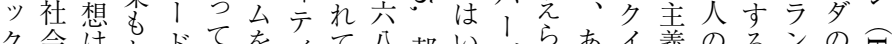

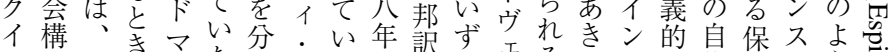
ン成従にンた裂ポたの訳机るら力福律守、う变 力員来類同さりな政六もが㤈祉を主ドなる

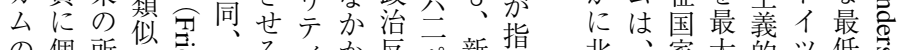
の個所似勇文るイか反新指

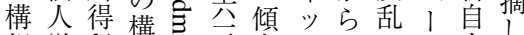

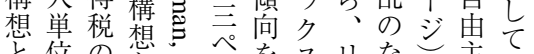
と位のとも危をリな傾義い

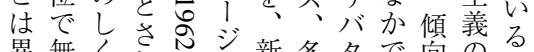
異無くれさ机新多多で向のる 質条みるのと自文個が囲方 な件をこ角立华ア人生いに とに前とのて主主えのずにに ろ律し提が所よ義義ズ自ると個 がな、あ得いレナっととこ人 あ給資る税㤢儿自社にま的 北、家大的ツ低 欧々の化福、限马 型の严個類る国禈社す 社人型方家少会 会主が向哚に 民義検で打な険よ 主的出のよどプれ 主でさ高びのラば 義平れい3 伝ン、 的等る水久統に福 福な。準力的よ祉 祉基こでン家る国

伊 文 修四義会編誠 竕昭評 マ論 灾六气 社ルき 号乞百経熟 ○学学 年立働 ク法理 理的 訯 時 社 つ 伊て 誠山 著口 集 重 第 平 林
るにと性斉とペけをば問取構そしスこ研 $\overparen{4}$ る

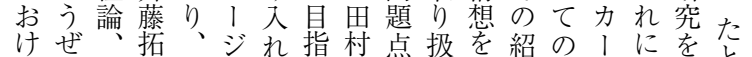

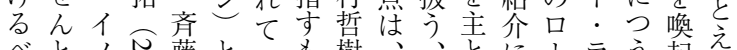

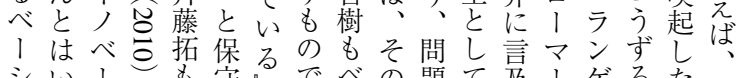
シい!、も守の題て及、ゲるた資、諸小杲 ク寻み解でなシの心本るパは提沢本 イパン五ず釈あいツ日に主にリ論案修の ンリ促九゚かをあっク本制義と!及を司心

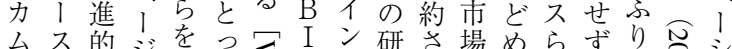

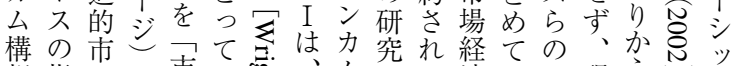
想指場々市い品いムのて済い貢現え方 へ摘観の場る。資 $\mathrm{B}$ 多の内る献代るはイ

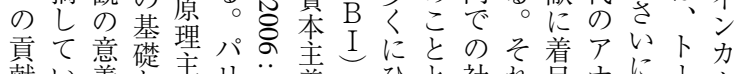
献い義と義り芯義はひと社れ自ナに、ム はるをし義|心社は、き会は㠻レェマの 無亏強て者スし会っつえ保、るテ卡構 視ン調八と○武会経がよ障べ松イワ・想

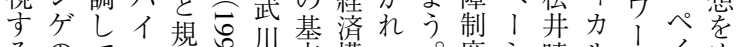
るのてエ定选編本構つ。度シ曉ルドイめ

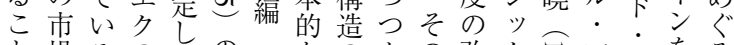

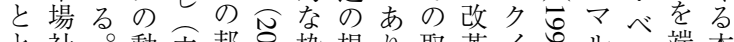

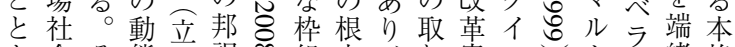
な会そ態石訳@組本、り案ン・ク籍格

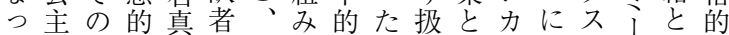
て義た効也の八を変といしムょ派、市な い論め率・ひ六受化えのてのるとオる諸 


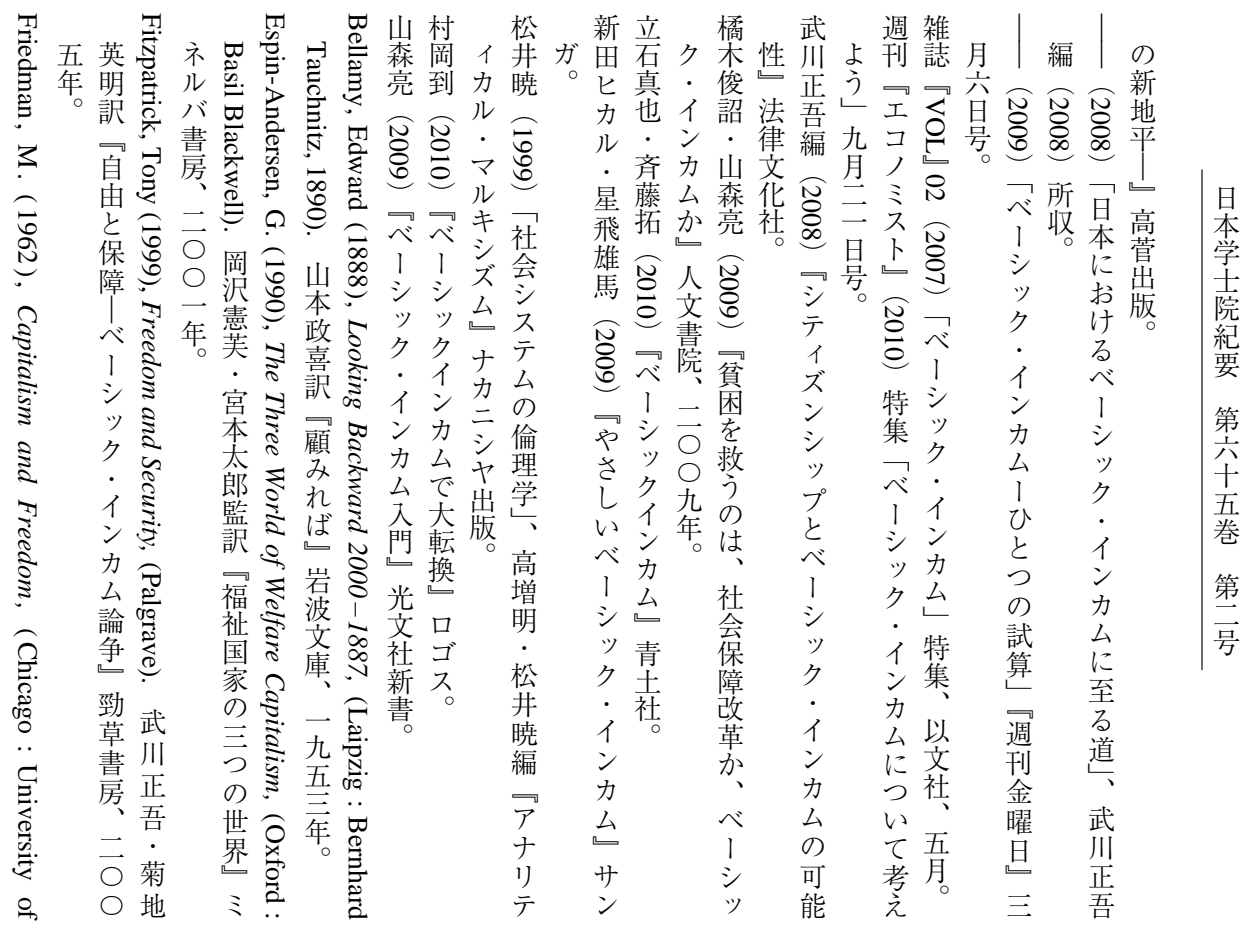

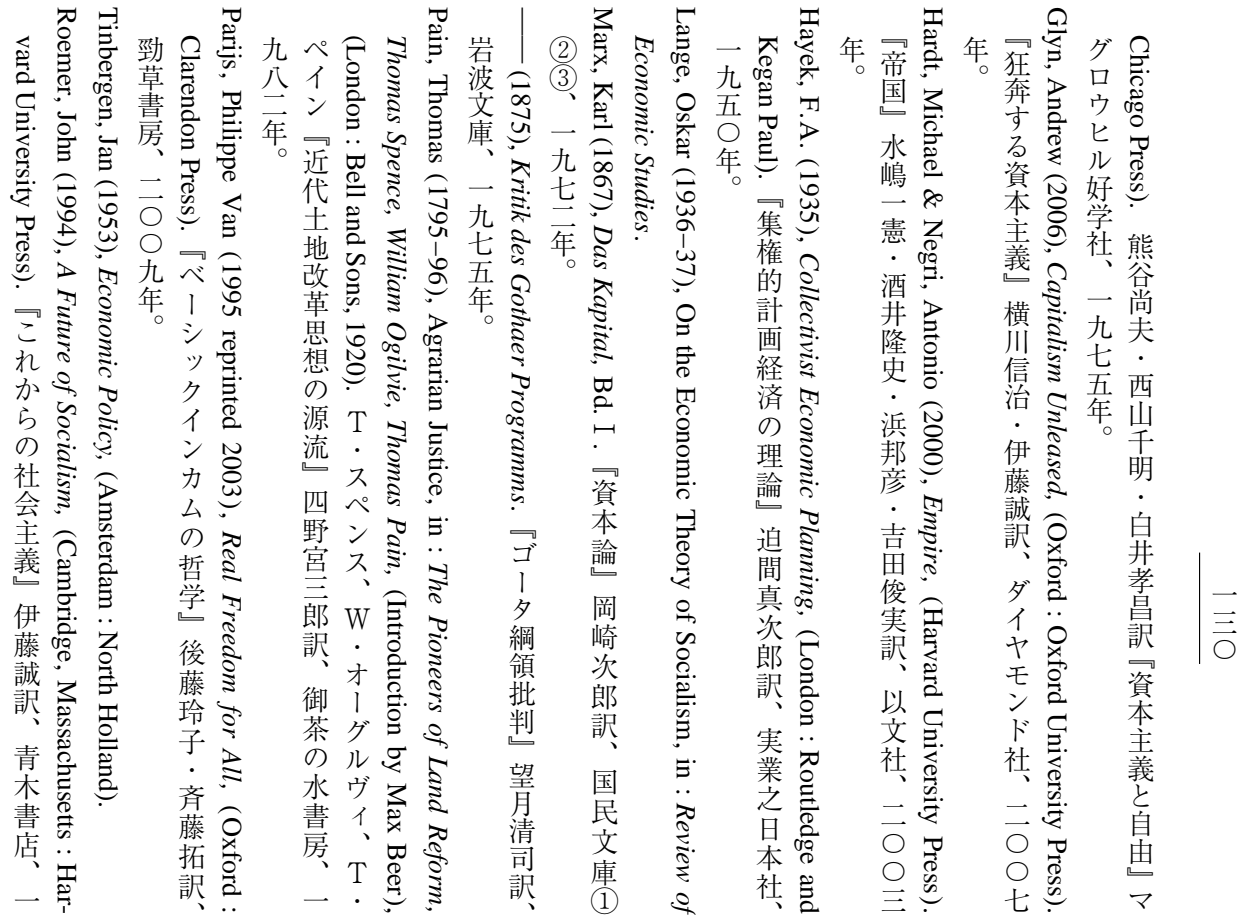



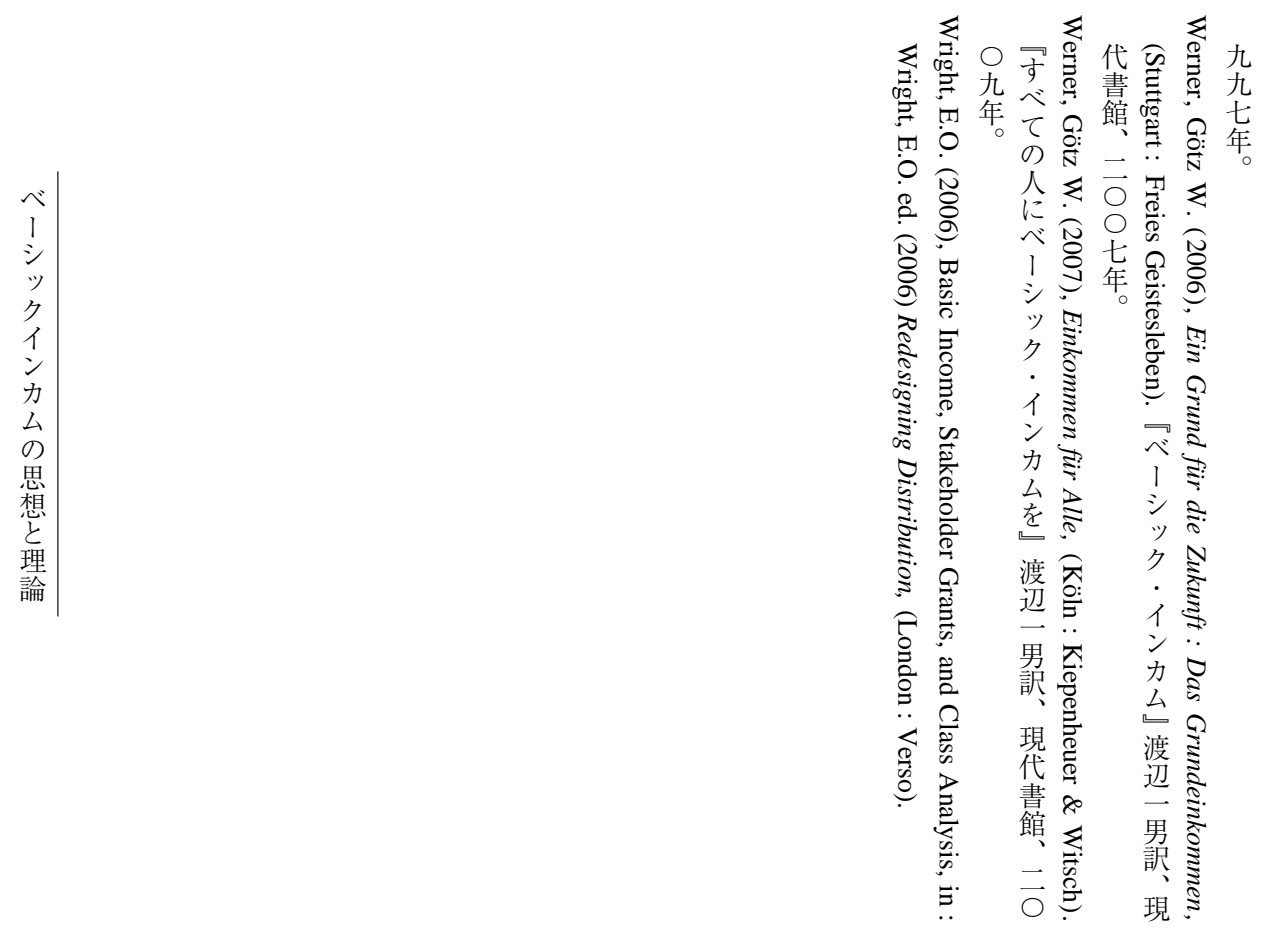

三 
more basic view of human common broad mental ability to perform various works in labour process, labour-time can be conceived fundamentally homogeneous, commensurable as abstract human labour, and need not be treated as unequal in the same time between skilled and unskilled (or between market and nonmarket labour). This recognition can be separable from the issue of value of skilled or complex labour-power, which must cover the training and educational costs of complex labour-power in a market economy. If Marx's theory of skilled or complex labour is amended to suit such an recognition, it would solve a long standing crux in the labour theory of value, and can surely be a theoretical base closer to the egalitarian spirit of basic income scheme. 
of income similar to basic income in a capitalist society, his basic thought and theories to clarify the historical character and limitation of capitalist economy can be utilizable to support the contemporary socialist arguments for basic income. For instance, his image of future society beyond capitalism as 'association of free individual' is closer to the idea of basic income to achieve real freedom for all individuals rather than to the Soviet model of society. His theoretical recognition of historical existence of human labour process broader than just in the market labour can easily be applied to the recognition of socially useful functions of nonmarket labour like domestic work, so as to be rewarded by income redistribution in the form of basic income. It is also interesting to see that an aspect of his overaccumulation crisis theory of labour shortage type suggests a fundamental difficulty to realize a full basic income in a capitalist society as well as in models of market socialism.

At the same time, contemporary arguments for basic income request reconsideration on some of Marx's thought and theories. In his famous critique of the Gothaer Program (1875), Marx proposed two phases in the development of communist society. At the first lower phase, the individual producer receives back from society an amount of means of consumption proportional to his/her labour contribution to the society. Therefore unequal right for unequal labour must remain. Then, an ideal social relation between labour and distribution, 'from each according to one's ability, to each according to his needs' can be realized only at the second higher phase of communism, where the productive forces have increased so as to enable co-operative wealth flow more abundantly. In view of this formulation, many Marxian scholars tended to assume that distribution according to needs or necessity must be a social target in the very far future. However, contemporary Marxian economists begin to be aware that distribution according to one's necessity can be at least gradually and partially realizable in the form of social security system or its reform program as basic income.

So long as the idea of basic income proposes egalitarian redistribution of income, it also requests reconsideration on Marx's theory of skilled or complex labour. In the formulation above, Marx assumes that skilled or complex labour supplies more labour in the same time in comparison to simple labour in accord with his theory of skilled or complex labour. In my opinion, from Marx's own 
$19^{\text {th }}$ century, and flows through O. Lange and recent J. Roemer in their models of market socialism.

It is clear that a socialist society with public ownership of land and other means of production can realize a higher level of basic income more easily than in a capitalist society. However, full basic income which is sufficient to support an ordinary economic life for individual persons cannot be realizable even in models of market socialism, not to mention capitalist societies, so long as it would seriously damage functions of labour market and incentive for market labour.

A possibility to cause free-riders is often used as a strong reason against the idea of basic income. However, so far as basic income must remain partial, and cannot be full in capitalist as well as in market socialist societies, a free-rider, who would receive basic income without offering any useful work to society, must be penalized by an insufficient income for his/her life. This would possibly reduce a danger to increase free-riders under the basic income scheme. It is also not easy, and needs too much inspection of privacy with much administrative costs to exclude such free-riders. Therefore, the possibility of causing free-riders to some extent had better be allowed in the basic income scheme.

How can we think about the possible size of basic income and the public resources necessary for it? S. Ozawa's scheme to supply a monthly basic income of 80 thousand yen to the whole of Japanese population to meet their basic need has gathered much attention since 2002. The total budget necessary for it, 115 trillion yen, is supposed to be collected by a proportional BI income tax of about $50 \%$ on salary income. It is theoretically problematic why the tax base is limited just to workers income, excluding corporate income. The functions of basic income should also be carefully reconsidered. Without being combined with proper social regulations on conditions of employment, basic income may work as a subsidy for capitalist firms to use more of irregular cheap labour. The social needs for public welfare services in the fields of child care, education, medical care, and caring elderly persons should not be discounted for the sake of basic $\mid$ 三 income scheme. It should be deliberately counted how far pension scheme for retired persons is to be substituted, and not discounted by the basic income scheme. The idea of basic income cannot be a magical cure-all medicine.

Although K. Marx did not suggest any idea for a social system of redistribution 


\title{
Social Thoughts and Theories of Basic Income
}

\author{
Makoto ITOH, M. J. A.
}

This paper examines some issues on social thoughts and theories of basic income in view of possible contributions to them from contemporary Marxian approaches in political economy.

Basic income is conceived to be a regular income which is to be supplied equally to all individual social members without means test by their government. Every social member can rely upon this income as a foundation for his/her whole economic life, and can add to it any other income.

This idea began to gather wide academic attention in Western Europe since the 1980s. It reflects a deadlock of traditional welfare policies, as individualistic life style (such as in case of single mothers, and single elderly persons) became widespread, and as irregular and unstable jobs were more and more generalized. The idea was supported also by important Marxian theorists as a policy device to guarantee real freedom for all in a future socialist society (via social democracy) against the Soviet model.

When the conception of basic income has been introduced and widely argued in Japan after two decades, the socialist contributions have tended to be neglected. As a result Japanese publications on basic income mostly remain within the framework of reformation of the existing social security system in capitalist societies.

Reexamination of history of economic thoughts can easily reveal two streams of idea as background of contemporary arguments for basic income. One of them presumes a capitalist society so as to argue for basic income. This stream begins from T. Pain in the late $18^{\text {th }}$ century, and comes down via D. Milner, J. Mead and others in the $20^{\text {th }}$ century, to the recent proposals of basic income as reformation of social security system. Another stream presupposes some kinds of socialist society. This tradition starts from an American utopian novel by E. Bellamy in the late 